\title{
Organic geochemistry, stable isotopes, and facies analysis of the Early Aptian OAE-New records from Spain (Western Tethys)
}

\author{
María Luisa Quijano ${ }^{\text {a,* }}$, José Manuel Castro ${ }^{b}$, Richard D. Pancost ${ }^{\text {c }}$, Ginés A. de Gea ${ }^{b}$, María Najarro ${ }^{d}$, \\ Roque Aguado ${ }^{\mathrm{b}}$, Idoia Rosales ${ }^{\mathrm{d}}$, Javier Martín-Chivelet ${ }^{\mathrm{e}}$ \\ a Departamento de Química Inorgánica y Orgánica, Universidad de Jaén, Campus Las Lazunillas, E-23071 Jaén, Spain \\ b Departamento de Geología, Universidad de Jaén, Campus Las Lagunillas, 23071 Jaén, Spain \\ c Oiganic Geochemistry Unit, Bristol Biogeochemistry Research Centre, The Cabot Institute, School of Chemistry, University of Bristol, BS8 1 TS, UK \\ 'Instituto Geológico y Minero de España, IGME, Ríos Rosas 23, 28003 Madrid, Spain \\ - Departamento de Estratigrafia-IGEO (CSIC-UCM), Universidad Complutense, 28040 Madrid, Spain
}

Keywords:

Early Aptian

Oceanic Anoxic Event 1a

Biomarkers

C-isotopes

Spain

\begin{abstract}
A B S T R A C T
The Early Aptian Oceanic Anoxic Event (OAE1a) is a time interval characterized by increased organic carbon accumulation in marine sediments, notable sedimentary and biotic changes, and abrupt carbon-isotope excursions indicative of significant major palaeoenvironmental changes linked to a perturbation in the global carbon cycle. Here we present the study of four sections recording the OAE1a (Early Aptian) in Spain, which are located in two broad basins respectively located in the South and the North of Iberia: the Southern Iberian Palaeomargin (Carbonero, La Frontera and Cau sections) and the Basque-Cantabrian Basin (Puentenansa section), which represent depositional settings ranging from shallow marine (distal ramp-Cau-and drowned platform -Puentenansa-) to pelagic environments (Carbonero, La Frontera). Biomarker compositions, $\mathrm{C}$-isotope profiles, biostratigraphic data and facies analysis from the four sections are correlated and integrated. The $\mathrm{C}$-isotope curves all present a clear negative excursion followed by a positive shift. The integration of the $\mathrm{C}$-isotope curves with the biostratigraphic data has been used to correlate the studied sections and to tentatively identify the eight segments formerly proposed from the Alpine domain, and subsequently identified in sections worldwide. Four main groups of compounds are present in all sections: $n$-alkanes, isoprenoids, hopanes and steranes. $n$-Alkanes and acyclic isoprenoids (pristane and phytane) are dominant in most samples. The hopanes are represented by a range of $C_{27}$ to $C_{35}$ components, with the specific isomers varying amongst the sections due to differences in thermal maturity. Steranes occur as a range of $C_{27}, C_{28}$ and $C_{29}$ isomers, whereas diasteranes only occur in the most thermally mature section (Carbonero). Other compounds of interest include gammacerane and dinosterane. Differences in thennal maturity appear to be the first order control on different biomarker assemblages amongst the studied sections. The Carbonero section is thermally mature, whereas the nearby La Frontera and Cau sections are immature. Puentenansa has intermediate values. Organic matter is derived from a range of terrestrial, marine and bacterial sources. The dominance of the $C_{2}$ sterane isomers in all sections suggests a strong contribution from higher plants. The presence of gammacerane indicates water column stratification, and high $\mathrm{C}_{2} / \mathrm{C}_{3}$ hopane ratios suggest anoxia at the water/sediment interface, respectively. Sedimentologic analysis also suggests anoxic conditions during sedimentation, but evidence for strong and persistent water column anoxia is equivocal. The correlation of the sections reveals that sedimentation of organic-rich facies started earlier in pelagic and later in the shallow marine settings, which can be related to an expansion of the favorable conditions for organic matter accumulation and preservation from deep marine waters to shallower platform environments during the development of OAE1a.
\end{abstract}

\footnotetext{
* Corresponding author. Tel: + 34953212741 ; fax: + 34953211876.

E-mail addresses: lquijano@ujaen.es (M.L. Quijano),jmcastro@ujaen.es (J.M. Castro), R.D.Pancost@bristol.ac.uk (R.D. Pancost), gadegea@ujaen.es (G.A. de Gea), m.najarro@igme.es (M. Najarro), raguado@ujaen.es (R. Aguado), i.rosales@igme.es (I Rosales), j.m.chivelet@geo.ucm.es (J. Marrín-Chivelet).
}

\section{Introduction}

The Cretaceous was generally characterized by a greenhouse climate state (Hallam, 1985; Wilson and Norris, 2001), with a reduced latitudinal temperature gradient (Huber et al., 1995; Hay, 2008), elevated $\mathrm{pCO}_{2}$ levels (Beerling and Royer, 2002, and references therein), and high sea level (e.g. Jenkyns, 1980; Skelton, 2003). In this context, significant short-term changes took place in the ocean-climate 
system, primarily reflected in the widespread deposition of organic carbon-rich marine sediments, whose relation to anoxic marine conditions led to the definition of Oceanic Anoxic Events (Schlanger and Jenkyns, 1976; Jenkyns, 1980). Subsequent research on OAEs have revealed that they represent notable perturbations in the global carbon cycle, which have been related to massive submarine volcanism, formation of oceanic plateaus, and increased rates of seafloor spreading (Leckie et al., 2002). These perturbations were reflected in rapid climate and environmental changes (Jenkyns, 2003; Dumitrescu et al., 2006; Hermoso et al., 2009) affecting both the marine and continental realms (e.g. Skelton, 2003).

Among the OAEs that punctuated the Cretaceous Period, the one that occurred during the Early Aptian (so called OAE1a) was one of the first identified and remains one of the most widely studied. It had a global extent (Arthur et al., 1990; Leckie et al., 2002) and a duration of 1.0 to $1.3 \mathrm{Myr}$ ( $\mathrm{Li}$ et al., 2008). Sediments recording this event have been recognized in the Tethys domain ("Selli level", Menegatti et al., 1998; Hochuli et al., 1999; Luciani et al., 2001; de Gea et al., 2003; Erba and Tremolada, 2004; Heimhofer et al., 2004; Aguado et al., 2008; de Gea et al., 2008b; Najarro and Rosales, 2008b; Rosales et al., 2009; Mehay et al., 2009; Millán et al., 2009; Najarro et al., 2011a, b; Stein et al., 2011, among others), in the Boreal domain (Gröcke et al., 1999; Föllmi et al., 2006), in the Pacific (Jenkyns, 1995; Ando et at., 2002; Price, 2003; Dumitrescu and Brassell, 2005), and Mexico (Bralower et al., 1999). Dramatic environmental changes occurred in association with OAE1a in settings ranging from continental to pelagic, and particularly in shallow marine carbonate platforms. Among the most striking time-related phenomena were the "nannoconid crisis" (Erba, 1994; Aguado et al., 1999; Erba et al., 2010), profound changes in the marine biota (e.g. Bralower et al., 1994; Erbacher et al., 2001; Leckie et al., 2002), and drastic perturbations in land vegetation and in continental weathering (Föllmi et al., 2006). Nevertheless, other studies suggest that major $\mathrm{pCO}_{2}$ and vegetation changes did not occur during OAE1a (Heimhofer et al., 2004).

The impact ofOAE1a on shallow carbonate platform environments has been analyzed in several studies. One major environmental perturbation is the widespread drowning event recorded at multiple sites (i.e. Weissert et al., 1998; Föllmi et al., 2006; Castro et al., 2008; Najarro et al., 2011a; Castro et al., 2012). In addition, notable faunal and facies changes in carbonate platforms have been related to the OAE1a (i.e. Huck et al., 2012), including the remarkable widespread development of Lithocodium-Bacinella episodes in the Tethys domain (Immenhauser et al., 2005; Bover-Arnal, 2010; Rameil et al., 2010).

A pervasive feature ofOAE1a stratigraphic successions is the series of pronounced isotopic excursions, first negative and then positive, that occur in both $\delta^{13} \mathrm{Ccarb}$ and $\boldsymbol{1}^{13} \mathrm{Corg}$ (e.g. Menegati et al., 1998; Leckie et al., 2002; de Gea et al., 2003; Herrle et al., 2004, among others). The widespread documentation of these features of the carbon isotope profile in numerous successions of marine carbonate and pelagic sediments from the aforementioned Tethys, Boreal and Pacific regions enables their use as a tool for stratigraphic correlation and as a record of the global perturbations of the carbon cycle. Although there is general agreement that the positive excursion in sedimentary ${ }^{13} \mathrm{C}$ values arises from increased burial of organic matter during the $\mathrm{OAE}$, multiple explanations have been proposed to explain the negative carbon isotope excursion at the onset of OAE1a and, by extension, the causal mechanism. One explanation is that emplacement of large igneous provinces (LIPs; e.g. Ontong-Java and Manihiki Plateaus: Larson, 1991; Larson and Erba, 1999; Tejada et al., 2009; Mehay et al., 2009) raised atmospheric $p \mathrm{CO}_{2}$ and enhanced nutrient fluxes to the ocean. Other potential triggers include dissociation of gas hydrates releasing methane in continental margin sediments (Beerling and Royer, 2002; Jahren et al., 2005), or increased recycling rates of ${ }^{12} \mathrm{C}$ and nutrient-rich intermediate waters linked to changes in ocean productivity (Menegatti et al., 1998; Larson and Erba, 1999; Erba and Tremolada, 2004; Weissert and Erba, 2004).

This paper presents the study of four sections recording the OAE1a in Spain, from two different basins (Southern Iberian Palaeomargin and North Cantabrian Basin, Fig. 1), and also representing different palaeogeographic settings (shallow marine and pelagic settings). The sections have been characterized using a combination of isotopic, elemental and biomarker approaches. The latter have been widely used in the investigation of OAEs, including the assessment of marine productivity, terrestrial vs. marine sources of organic matter, and the redox state of the ocean (Meyers, 1997; Pancost et al., 2004). The timing of $\mathrm{C}$-rich sediment deposition is interpreted with respect to the local carbon isotope stratigraphy, with biomarker and elemental analyses being used to further constrain changes in organic carbon inputs and differences in thermal maturity among the four sections. Overall, the integration of stratigraphy and geochemistry, and the correlation with reference sections, has led to present a sedimentary model which assess mechanisms for the spread of anoxia, taking into consideration global and regional effects.

\section{Geological setting}

\subsection{Palaeogeographic framework}

During Aptian times the sedimentary basins of Iberia were strongly influenced by the relative motions of the contiguous Eurasian and African plates (Fig. 1). The initiation of the seafloor spreading in the North Atlantic, which started very early in the Cretaceous, led to a decrease in the sinis movement between Iberia and Africa that had prevailed during part of the Jurassic (Ziegler, 1988), and to a phase of rapid anticlockwise rotation of Iberia relative to Europe that would culminate in seafloor spreading in the Bay of Biscay from middle Aptian times onwards (Olivet, 1996; Vergès and García-Senz, 2001). In that geodynamic framework, extensional tectonics prevailed in the main sedimentary basins, including the two considered in this paper: the North Cantabrian Basin (NCB), which belonged to the northem margin of the Iberian plate, and the Southern Iberian Palaeomargin (SIPM) (Fig. 1). That extensional tectonism experienced a strong phase during the latestJurassic to the Hauterivian, followed, during the Barremian-Aptian, by an interval of smaller tectonic movements but larger subsidence rates, that favored the development of wide and thick carbonate platforms (including the Urgonian facies) in the shallow areas of the basins (e.g., Martín-Chivelet et al., 2002; Vera, 2004).

The Lower Cretaceous sequence of the SIPM includes thick successions $(>3000 \mathrm{~m}$ ) of carbonates and siliciclastics that were deposited in shallow platforms (mostly in the so-called Prebetic Zone, Fig. 2A) and hemipelagic/pelagic settings (dominant in the Subbetic Zone, Fig. 2A) (e.g. Ruiz-Ortiz, 1980; Martín-Chivelet et al., 2002; Vera, 2004). The configuration of the SIPM was defined by a series of basin-scale troughs and swells, bounded by large extensional faults roughly parallel to the continental margin, that were initiated in the Middle Jurassic (e.g., Azéma et al., 1979; García Hernández et al., 1980; Vera, 1988; Ruiz-Ortiz et al., 2001). This tectonic pattern controlled strong differential subsidence and deposition rates. The stratigraphic sections herein considered correspond to depocentral areas in both the Prebetic (Cau section), and the Subbetic (Carbonero and La Frontera sections) (Fig. 2A).

The North Cantabrian Basin (NCB) was a relatively small $(\approx 20 \times 80 \mathrm{~km}), \mathrm{E}-\mathrm{W}$ elongated sub-basin, which belonged during the Mesozoic to the larger Basque-Cantabrian Basin (BCB). Located in the northwestern margin of the $\mathrm{BCB}$, this sub-basin behaved independently for most of the Cretaceous, and was relatively less subsident than other areas of the BCB. It was separated from the rest of the basin to the east by a $\mathrm{N}-\mathrm{S}$ complex fault structure (Río Miera Flexure; Feuillée and Rat, 1971). The NBC was generated by rifting tectonics linked to the opening of the Bay of Biscay and 


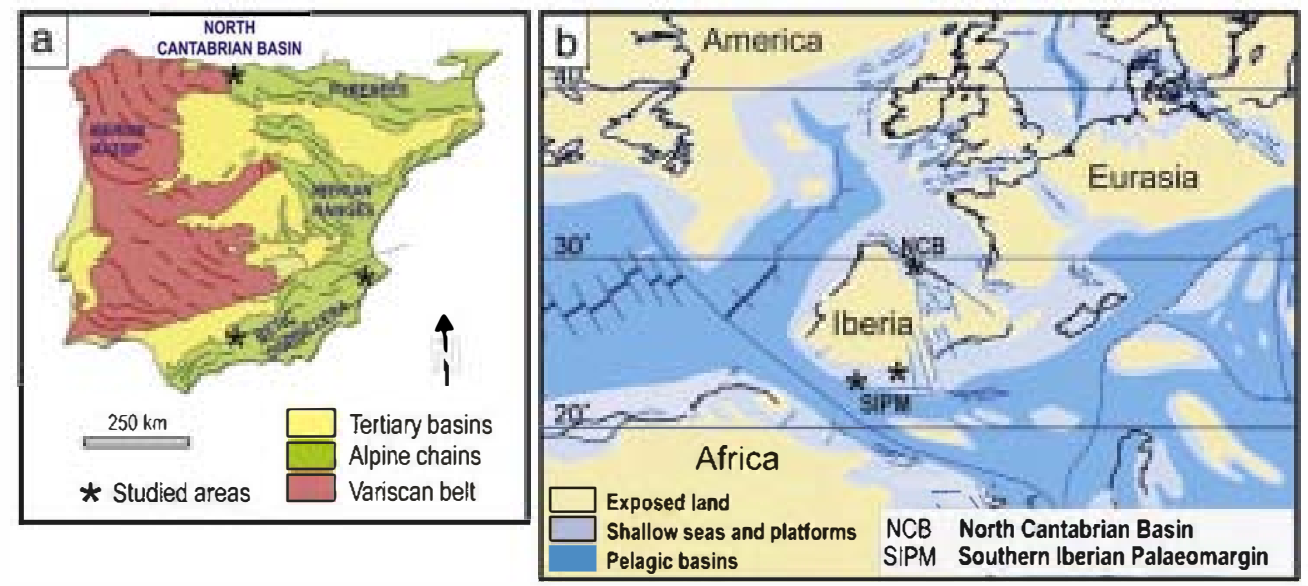

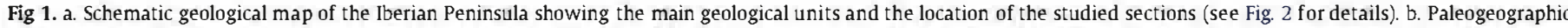

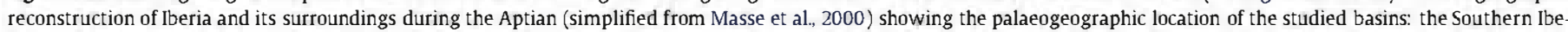

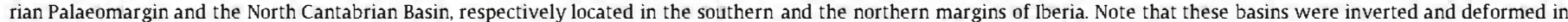
the Alpine Orogeny during the Tertiary, and are now respectively incorporated into the External Zones of the Betic Cordillera and the Western Pyrenees.

North Atlantic during the Iate Jurassic and the Early Cretaceous. This tectonism structured a series of horsts and grabens, mainly outlined by the presence of N-S, NE-SW, and E-W oriented faults, which controlled differential subsidence and sedimentation patterns at least during Barremian-Albian times (Najarro et al., 2007, 2011a). The Lower Cretaceous sediment infill includes relatively thick successions (up to $2000 \mathrm{~m}$ thick) of siliciclastics and carbonates, deposited in environments that ranged from fluvial/estuarine to open marine. The studied section corresponds to the Puentenansa road outcrop, near the village of Rábago (Fig. 2B). This area, characterized by moderate subsidence during sedimentation, corresponded to the footwall block of the N-S Bustriguado synsedimentary fault, which is considered as a Cretaceous left-lateral transfer fault (Garcia-Senz and Robador, 2009; Najarro et al., 2009).

Interestingly, the studied successions in the SIPM and the NCB, despite their proximity from a global perspective, were isolated from each other during deposition because of the palaeogeography of Iberia and the palaeoceanography of the surrounding seas. The SIPM belongs to the westemmost part of the northern margin of the Tethys, whereas the NCB belongs to the North Atlantic realm. That relative isolation favored, for example, the development of separate faunal (sub)bioprovinces during Cretaceous times (e.g., Caus and Hottinger, 1986; Caus et al., 2009). Beyond regional tectonics and palaeogeography, the sedimentation in the basins of Iberia should be also influenced in Aptian times by eustatic changes (e.g., Immenhauser et al., 1999; Immenhauser, 2005) and regional climate. At that ime Iberia was located approximately between $23^{\circ}$ and $33^{\circ}$ North latitude, with a ropical to subtropical climate (e.g., Masse et al., 2000).

\subsection{Previous stratigraphic data of the studied sections}

\subsubsection{Southern Iberian Palaeomargin (SIPM)}

Three sections have been previously studied, two from the pelagic Subbetic domain (La Frontera and Carbonero), and one other from the Prebetic domain (Cau section), which represents shallow marine settings.

2.2.1.1. La Frontera section. This section is located in the South of the Jaén province (Fig. 2A) and was deposited in a pelagic environment, in a rapidly subsiding area bounded by extensional faults. In this area of the Subbetic Zone, the Barremian is represented by a pelagic rhythmite of the Carretero Formation, whereas the Aptian is represented by the Carbonero Formation, comprising dark marls with an interval of black shales in the Early Aptian, interpreted as the local record of OAE1a (Fig. 3). Here, the presence of calcareous nannofossils has led to the identification of the Hayesites irregularis and lower Rhagodiscus angustus biozones (Fig. 3). A detailed biostratigraphic characterization of this section, based on planktonic foraminifers, radiolarians and ammonites, can be found in Aguado et al. (1992a) and de Gea (2004).
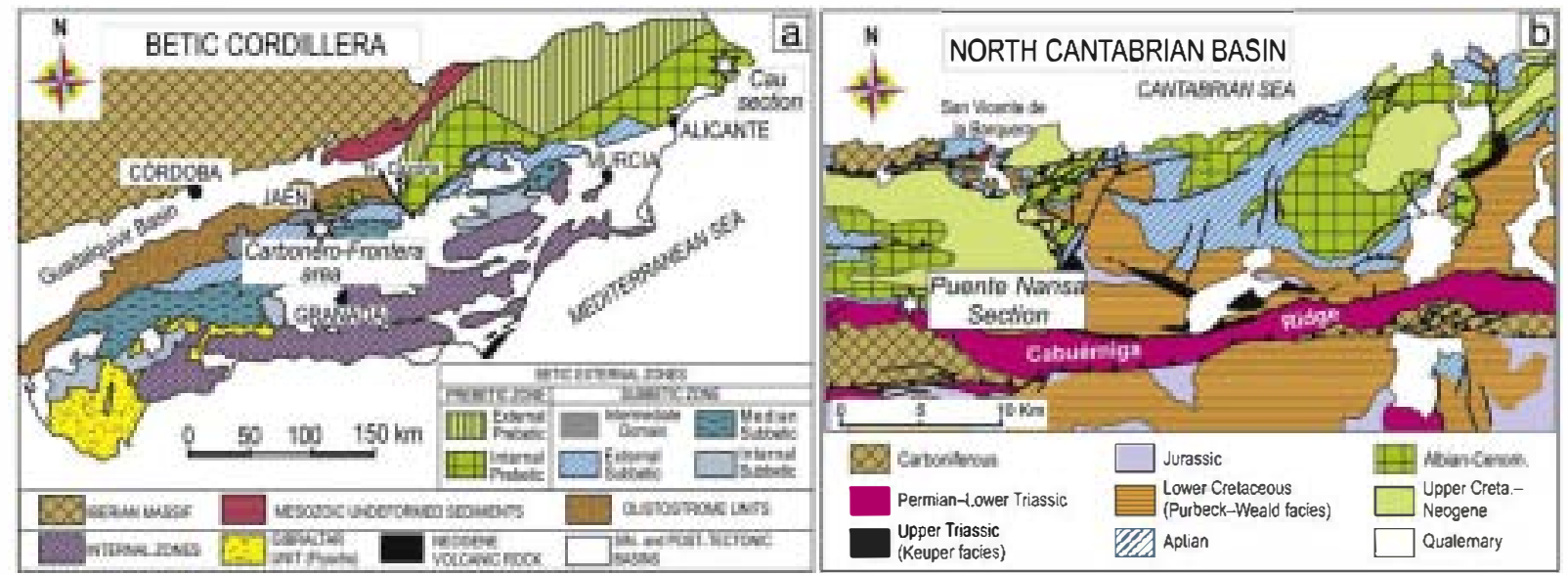

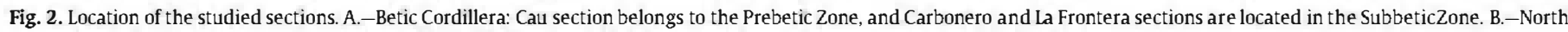
Cantabrian Basin: Puentenansa section is located in La Florida area, which formed in the south- western margin of the Basin. 
2.2.1.2. Carbonero section. This section is located in the South of the Jaén province, fifteen kilometres westward of the La Frontera section. In spite of the proximity, the Carbonero Formation here has strong differences to the La Frontera section and occurs as a rich association of facies, including marls and marlstones, black shales, radiolarian marls, siliceous shales, calcareous turbidites, cinerites, and concretions of barite and carbonate. de Gea et al. (2008a) provided a detailed study of several sections within the area of Carbonero section. They proposed a model of a small subsiding pelagic subbasin bounded by active faults leading to scarps feeding the turbidite levels, associated with volcanic activity. This small sub-basin has a more complete stratigraphic record than the surrounding areas, with a locally restricted environment leading to high contents of organic matter, along with the development of barite concretions, interpreted to reflect anoxic conditions (Molina and HernándezMolina, 1993; Bréheret and Brumsack, 2000; de Gea et al., 2008a). Characterization of nannofossil assemblages has led to the recognition of the Micrantholitus hoschulzi, H. irregularis and lower part of R. angustus biozones (Aguado et al., 1992b; Molina et al., 2001; Fig. 3).

2.2.1.3. Cau section. This section is located in the NE of the Alicante province (Fig. 2A) and represents the distal parts of a shallow carbonate ramp. In this setting, hemipelagic sedimentation took place during the late Barremian to late Aptian, when a progradational episode led to the deposition of shallow platform carbonates during the latest Aptian-Albian. The late Barremian to late Aptian is represented by the Almadich Formation, comprising hemipelagic marls and marlstones with ammonites, planktonic foraminifers and calcareous nannofossils. This formation includes a horizon of black marls corresponding to the Early Aptian OAE1a (Fig. 4). This black marl interval occurs in the lower part of the Schackoina cabri planktonic foraminifer biozone, $H$. irregularis nannofossil biozone, and corresponds also to the 'nannoconid crisis' (Aguado et al., 1999; de Gea et al., 2003). The high organic matter content along with the planktonic foraminifers association (with elongation of the chambers) have been proposed to be related to anoxic-dysoxic conditions in the water column during sedimentation (Aguado et al., 1999; de Gea et al., 2003). The stratigraphy, biostratigraphy and isotope chemostratigraphy of the Cau section have been presented in detail in previous publications (Aguado et al., 1999; de Gea et al., 2003; Castro et al., 2008).

\subsubsection{North Cantabrian Basin (NCB)}

The Puentenansa section is located to the West of Cantabria, in the eastern edge of the North Cantabrian Basin. It is well exposed alongside the Puentenansa road. In this outcrop, the Aptian succession lies unconformably on the Permian to Early Triassic sedimentary rocks. The Early Aptian lithostratigraphy in this area is complex, including four formations: the Rábago and Umbrera Formations (lower Bedoulian), which consist of shallow platform limestones, marls and sandstones; the Patrocinio Formation (mostly early Bedoulian, Deshayesites weissi ammonite biozone and middle upper part of the $H$. irregularis nannofossil biozone; Rosales et al., 2009; Najarro et al., 2011b), comprising open marine, black marls and marly siltstones. These deposits, which represent the local record of the OAE1a, reflect the shutdown of the shallow water carbonate factory, as the result of a combined
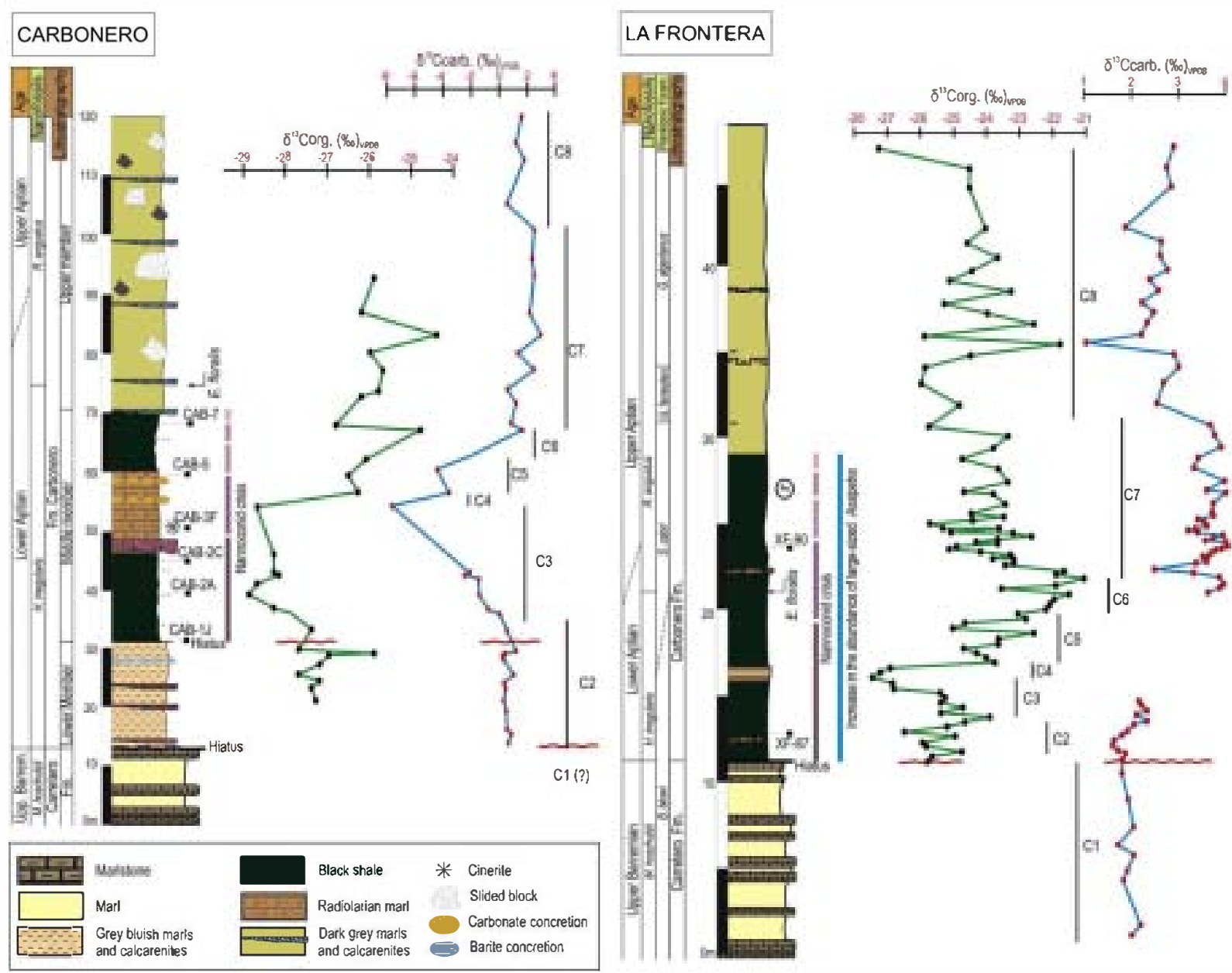

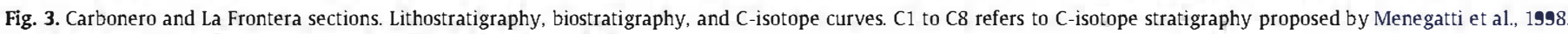
Samples referred in sections are those selected for biomarker analysis. 


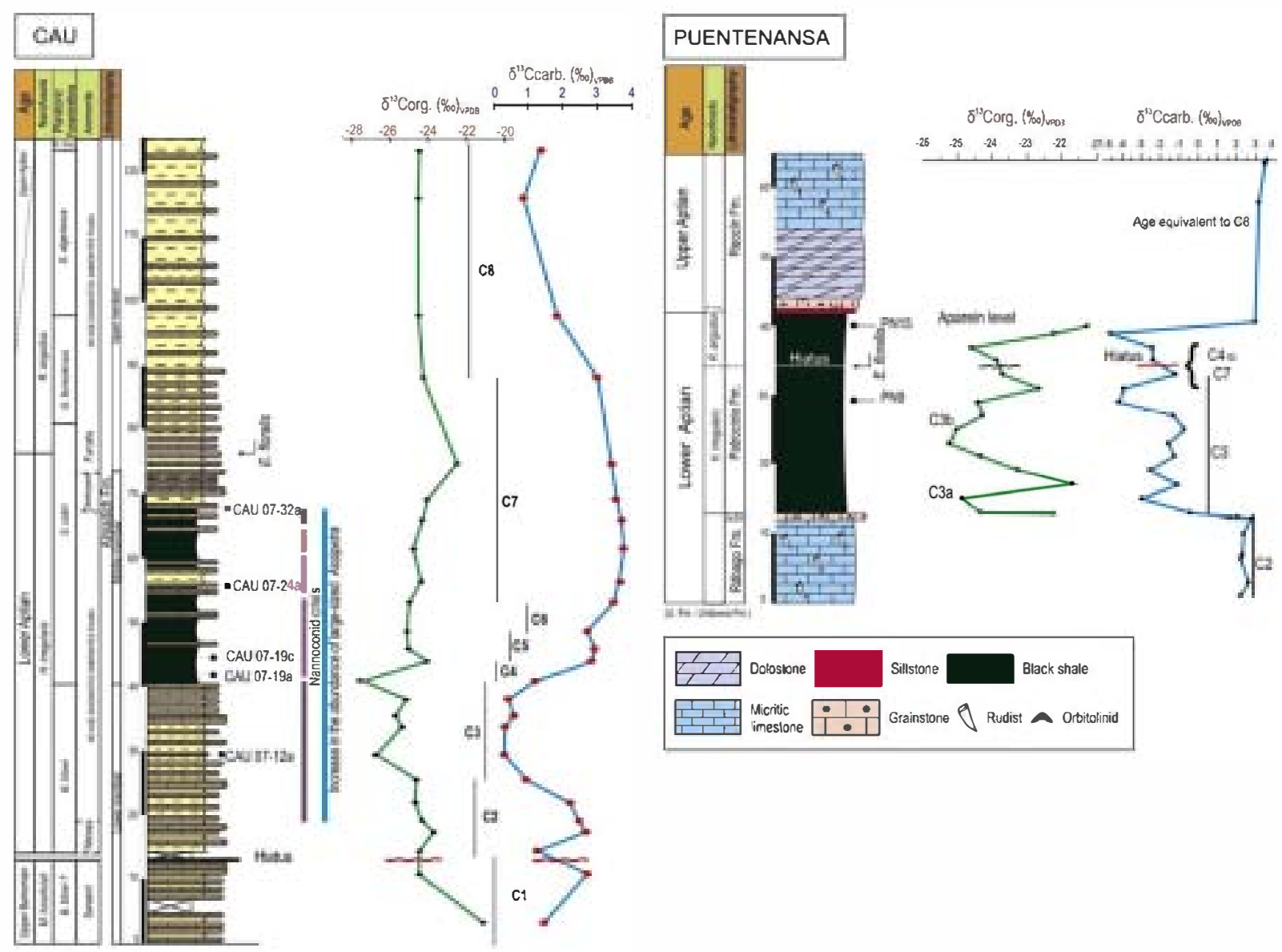

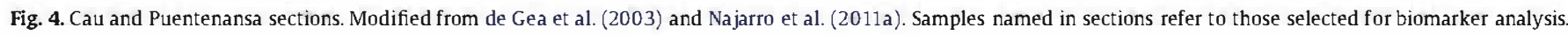

action of a relative sea-level rise and environmental stress, and record a net deepening-upward trend leading to a drowned platform (Najarro et al., 2011a). Nannofossil assemblages from the Patrocinio Formation allow the recognition of the $H$. irregularis and lower $R$. angustus biozones (Fig. 4), showing the presence of a stratigraphic gap in the Patrocinio Formation of this area that lasts until the lower Gargasian and which affects the record of OAE1a (Najarro et al., 2011b). Finally, in this section the Reocin Formation (Gargasian), comprising shallow platform limestones, overlies the Patrocinio Formation.

\section{Methods}

\subsection{Stratigraphy and biostratigraphy}

Through previous extensive field work, the selected sections have been intensively inves igated. As a result, the lithology, biostratigraphy and sedimentology of each section has been previously described in detail and finally integrated in a regional stratigraphic context (Aguado et al., 1992a,b, 1999; Castro, 1998; Molina et al., 2001; de Gea et al., 2003; de Gea, 2004; de Gea et al., 2005, 2008b, 2008c; Najarro et al., 2007; Najarro and Rosales, 2008a,b; Najarro et al., 2011a,b).

To allow further and integrated analyses, and to refine the dating and correlation between the different sections, all four were resampled for geochemical analyses and calcareous nannofossil and planktonic foraminiferal characterisation. The marly lithotypes were preferred for sampling in order to obtain the best preserved assemblages. In the Carbonero section, about 33 samples were collected at irregularly spaced intervals $(50 \mathrm{~cm}-5 \mathrm{~m}$ ) along a $120 \mathrm{~m}$ thick sucession of marls, marly limestones, black shales and radiolarian marls (Carbonero Formation), spanning the Lower Aptian-lower part of the Upper Aptian interval. The La Frontera section was sampled at a higher resolution, also at irregularly spaced intervals $(15-250 \mathrm{~cm})$, in order to characterize biostratigraphically and sedimentologically the small changes in facies and/or lithology. A total of 100 samples were collected from the marls, marly limestones and black shales of the Carretero and Carbonero Formations spanning the uppermost Barremian-lower part of the Upper Aptian interval. The Cau section was re-sampled for more detailed dating and for geochemical analyses. Finally, in the Puentenansa section, 15 samples of marls and marly siltstones were collected across the Lower Aptian Patrocinio Formation at approximately regular intervals of $2 \mathrm{~m}$, and another 10 limestones were collected from the platform units below and above the Patrocinio Formation.

For calcareous nannofossil characterization, simple smear slides were prepared following standard procedures (Bown and Young, 1998). No physical concentration or separation was applied in order to retain the original assemblage composition. A polarizing light microscope at $1250 \times$ magnification was used to investigate the nannofossil assemblages through, at least, a longitudinal traverse of the smear slide (200 fields of view). Also, a fraction of each sample was disaggregated and washed through sieves, the residue being separated into three fractions ( $>200 \mu \mathrm{m}, 100-200 \mu \mathrm{m}$ and 50-100 $\mu \mathrm{m}$ ). For each sample, the two great sized residues were investigated for planktonic foraminiferal content, although the richest assemblages were found in the $100-200 \mu \mathrm{m}$ residues. A portion of the selected samples was separated for geochemical analyses, including carbon isotope, elemental and biomarker characterization.

\subsection{Oxygen and Carbon isotopes}

Oxygen and carbon stable isotope analyses were performed on marls collected from the four sections, and also on carbonates from 
the Puentenansa section. Carbonero and La Frontera samples were powdered using an agate mill. The ${ }^{13} \mathrm{C}$ values of carbonates were determined by treatment with $103 \%$ orthophosphoric acid using a VG Isocarb system thermostatized at $90{ }^{\circ} \mathrm{C}$. The produced $\mathrm{CO}_{2}$ was analyzed with an IRMS (Isotope Ratio Mass Spectrometer) VG Prism II. For analysis of organic matter $\delta^{13} \mathrm{C}$ values, samples were treated with $3 \% \mathrm{HCL}$ for $24 \mathrm{~h}$ to remove carbonates and then analyzed with an elemental analyzer Carlo Erba 1108 coupled to a IRMS VG Isochrom in continuous flow mode. These analyses were performed at the Stable Isotope Laboratory (SIDI) of the Universidad Autónoma of Madrid and Servicio General de Isótopos Estables of the University of Salamanca (Spain). The results are expressed in the common $\delta$-notation in per mil (\%) relative to the VPDB-standard. The international carbonate standard NBS-19 (National Bureau of Standards; ${ }^{13} \mathrm{C}=1.95 \%$ and $\delta^{18} \mathrm{O}=-2.20 \%$ ) was used to calibrate to V-PDB, with an average precision of $0.1 \%$ for $\delta^{13} \mathrm{Ccarb}$ and $0.15 \%$ for $\delta^{13}$ Corg analyses. A description of the method used for the Puentenansa and Cau sections has been published in Najarro et al. (2011b) and de Gea et al. (2003), respectively.

\subsection{Elemental analyses and total organic carbon}

A total of 33 samplesfrom the studied sections were analyzed for total organic carbon (TOC) concentrations and elemental composition (CNHSO and XRF). The CNHSO and X-ray fluorescence analyses were performed in the Centro de Instrumentación Científica of the Universidad de Jaén, with a Thermo Finnigan FlashEA1112 CHNS-OElementalAnalyzer, and an X-Ray expectrometer Bruker AXS model Pioner S4 explorer, respectively. The TOC analyses were performed in the Centre of Atomic Spectrometry of the Universidad Complutense (Madrid) with a SHIMADZU TOC-V device that performs the $680^{\circ} \mathrm{C}$ combustion catalytic oxidation method. The TOC concentration was determined by subracting the inorganic carbon (IC) concentration from the total carbon (TC) in each sample.

\subsection{Biomarkers}

A collection of 15 samples, with an emphasis on the OAE1a intervals, were selected from the studied sections (Figs. 3 and 4), in order to characterize the thermal maturity and organic source inputs. The samples were externally washed with dichloromethane (DCM) to remove contamination from handling and then crushed using a Pulverissete 5 agate mill. The crushed samples were Soxhlet extracted for $48 \mathrm{~h}$ with $500 \mathrm{ml} \mathrm{DCM} / \mathrm{MeOH}$ (80:20). Activated copper turnings were added to the solvent flask to remove elemental sulphur from the Carbonero samples. After extraction, the turnings were removed, and the solvent volume was reduced under reduced pressure. The extracts were separated into three fractions by column chromatography using activated alumina and sequential elution with hexane (saturated hydrocarbons), hexane:dichloromethane (9:1) (aromatic compounds), and methanol (polar compounds).

The saturated hydrocarbon fractions were analyzed with gas chromatography-mass spectrometry (GC-MS). GC-MS was carried out on a Thermo DSQ II gas chromatograph connected to a Thermo Trace Ultra mass spectrometer in the Centro de Instrumentación Cientifica of the Universidad de Jaén, and a ThermoQuest Trace GC-MS housed in the Organic Geochemistry Unit (School of Chemistry) of the University of Bristol. The GC was fitted with a fused silica capillary column (Supelco Equity-5; $30 \mathrm{~m} \times 0.25 \mathrm{~mm} \times 0.25 \mu \mathrm{m}$ ) and was operated with helium as carrier gas. The samples (in hexane) were injected at $70{ }^{\circ} \mathrm{C}$ and the oven was subsequently programmed to $130{ }^{\circ} \mathrm{C}$ at $20^{\circ} \mathrm{C} / \mathrm{min}$ and then at $4{ }^{\circ} \mathrm{C} / \mathrm{min}$ to $300{ }^{\circ} \mathrm{C}$ where it was held for $25 \mathrm{~min}$. Biomarkers were identified by comparison of mass spectra and retention time with those reported in the literature (i.e. Peters et al., 2005); for the identification of gammacerane an authentic standard purchased by Chiron was coinjected.

\section{Results}

\subsection{Chemo- and biostratigraphy}

The carbonate $\left(\mathrm{C}_{\text {cart }}\right)$ and bulk organic carbon $\left(\mathrm{C}_{\mathrm{org}}\right)$ isotopic profiles are shown for each of the four sections (Figs. 3 and 4). Part of the data included in the curves comes from previous papers dealing with single sections (see de Gea et al., 2003 for the Cau section, and Najarro et al., 2011b for the Puentenansa section). The biostratigraphy of these successions is mostly based on the references cited and also on new data from this study. The reference curve used here for correlation is that published by Menegati et al. (1998), because is the more widely used (i.e. Immenhauser et al., 2005; Föllmi et al., 2006; Dumitrescu and Brassell, 2006; Stein et al., 2011; Jenkyns et al., 2012), and it is focused on the same time interval studied here. Other more recent proposals of subdivision of the Barremian-Aptian C-isotope curve have also been considered (Bralower et al., 1999; Wissler et al., 2003; Herrle et al., 2004).

\subsubsection{La Frontera section}

The ${ }^{13} \mathrm{C}_{\text {carb }}$ values of the La Frontera section range between $1.0 \%$ and $4.0 \%$ (Fig. 3). The lowest 9 samples in the section, corresponding to the latest Barremian marls and marly limestones of the Carretero Formation (Micrantholithus hoschulzi nannofossil biozone, Aguado et al., 1992a), show little isotopic variation, with values of $\delta^{13} C_{\text {carb }}$ ranging from $1.8 \%$ to $2.1 \%$ (Fig. 3). A stratigraphic gap, including probably part of the uppermost Barremian and the lowermost Aptian, has been interpreted to exist at the top of this lower portion of the section, because the marker species Hayesites irregularis is not recorded in the uppermost part (uppermost Barremian) of the Carretero Formation and the overlying black facies of the Carbonero Formation are within the 'nannoconid crisis' interval (Fig. 3). This stratigraphic gap affects the complete lower member of the Carbonero Formation (lowermost Aptian), which is not represented in this section. A minor $0.5 \%$ positive excursion in carbonate, with a maximum value of $2.3 \%$ occurs within the middle member of the Carbonero Formation, in layers belonging to the $H$. irregularis nannofossil biozone and located within the interval corresponding to the "nannoconid crisis' (Fig. 3). This excursion is followed by $10 \mathrm{~m}$ of largely carbonatefree black-shales, after which the positive excursion apparently continues to a maximum value of $4.0 \%$. Eprolithus floralis was recorded in the first sample above the carbonate-free rocks. Within the following $8 \mathrm{~m}$ interval, corresponding to the lowermost part of the $R$. angustus nannofossil biozone and $S$. cabri planktonic foraminiferal biozone, the $\delta^{13} \mathrm{C}_{\text {cart }}$ values remain relatively high (minimum $3.2 \%$; average $3.6 \%$ ). High abundances of Assipetra, (A infracretacea and A terebrodentaria), including large-sized specimens (A infracretacea ssp. Iarsonii and A terebrodentaria ssp. youngii; Tremolada and Erba, 2002), characterize this interval from the base of the middle member of the Carbonero Formation (Fig. 3). The next $5 \mathrm{~m}$ of the isotopic profile display an overall negative trend reaching a minimum of $1.0 \%$, coinciding with the Globigerinelloides ferreolensis and lower part of $G$ algerianus planktonic foraminiferal biozones (Lower-Upper Aptian transition). Finally, $\delta^{13} \mathrm{C}_{\text {carb }}$ values in the uppermost $12 \mathrm{~m}$ of the investigated interval are characterized by a slight increasing trend (maximum $2.8 \%$ but also a marked minimum value of $1.9 \%$ ). This last interval is Late Aptian in age, and is characterized biostratigraphically by the upper part of G. algerianus planktonic foraminifer biozone.

The $\delta^{13} \mathrm{C}_{\text {org }}$ values of the La Frontera section range between $-21.0 \%$ and $-27.4 \%$, and present a continuous record of $C$-isotope data. Generally, the ${ }^{13} \mathrm{C}_{\text {org }}$ values parallel the ${ }^{13} \mathrm{C}_{\text {carb }}$ curve. In detail, a large negative excursion, from $-23.9 \%$ to $-27.4 \%$, occurs in the interval lacking a ${ }^{13} \mathrm{C}_{\text {carb }}$ record. The subsequent positive excursion is characterized by an increase in ${ }^{13} \mathrm{C}_{\text {org }}$ values to $-23.8 \%$ and this does parallel the ${ }^{13} C_{\text {carb }}$ profile. However, also present in the upper part of the 
$\delta^{13} \mathrm{C}_{\text {org }}$ profile are several high frequency and high amplitude variations, with maximum shifts of $4.0 \%$ 。 (Fig. 3).

\subsubsection{Carbonero section}

The samples from the Carbonero section were taken in the type area of the Carbonero Formation (de Gea et al., 2008a). In this section, a stratigraphic gap has been interpreted to exist between the uppermost Barremian marls and marly limestones of the Carretero Formation and the overlying bluish-grey marls with intercalations of calcareous turbidites comprising the lower member of the Carbonero Formation (Lower Aptian). This gap, with a lower extent than that observed in the La Frontera section, has been deduced on the basis of the absence of the nannofossil $H$. irregularis in the Carretero Formation. The bluish-grey marls of the lower member of the Carbonero Formation, containing moderate to high proportions of nannoconids and H. irregularis, predate the 'nannoconid crisis' event (de Gea et al., 2008a). The base of the overlying black shales and radiolarian marls of the middle member of the Carbonero Formation (local expression of the OAE $1 \mathrm{a}$ ), coincides with the onset of the 'nannoconid crisis'. For this reason, a new stratigraphic gap has been interpreted to exist in this section between the lower and middle members of the Carbonero Formation (de Gea et al., 2008a). Finally, the FO of the nannofosil $E$. floralis, has been recorded near the base of the alternation of greenish-grey marls and calcarenites of the upper member of the Carbonero Formation.

The Carbonero section has been analyzed at a lower resolution than the La Frontera section, but both the $\delta^{13} \mathrm{C}_{\text {carb }}$ and $\delta^{13} \mathrm{C}_{\text {org }}$ profiles are complete and largely parallel each other. Overall, they exhibit the same general trends as observed in the La Frontera Section (Fig. 3). ${ }^{13} \mathrm{C}_{\text {carb }}$ values vary between $3.1 \%$ and $-7.9 \%$. The lower $20 \mathrm{~m}$ of the section (lower member of the Carbonero Formation), have constant values around $0.8 \%$ but then increase slightly up to $1.2 \%$. The following $28 \mathrm{~m}$ is characterized by a dramatic negative trend to values of approximately $-7.9 \%$ in the radiolarian marls of the middle member of the Carbonero Formation. The next $15 \mathrm{~m}$ record a positive trend, up to $1.5 \%$, and the upper $80 \mathrm{~m}$ are characterized by generally elevated values (from 1 to $3 \%$ ).

The ${ }^{13} \mathrm{C}_{\text {org }}$ profile reproduces some of the major trends recorded by ${ }^{13} \mathrm{C}_{\text {carb }}$ values, albeit at a reduced amplitude. Values range from $-28.9 \%$ to $-24.4 \%$, although only a $2 \%$ o decrease occurs from 30 to $40 \mathrm{~m}$, such that the magnitude of the negative carbon isotope excursion is much smaller than that recorded by carbonates.

\subsubsection{Cau section}

The studied interval of the Cau section belongs to the Almadich Formation. The lower member of the Almadich Formation in the Cau section encompass the Upper Barremian to lowermost Aptian interval and consists of a rhythmic alternation of marly limestones and light grey marls. The FO of $H$. irregularis has been recorded immediately above a ferruginous surface located within this lower member. As the levels below the ferruginous surface were assigned to the M. hoschulzii nannofossil biozone, a stratigraphic gap, probably affecting the uppermost Barremian and the lowermost Aptian, was interpreted to exist within this lower member (Aguado et al., 1999). The onset of the 'nannoconid crisis' event and an increase in the abundance of large-sized morphotypes of the nannofossil genus Assipetra (A. infracretacea ssp. larsonii and A. terebrodentaria ssp. youngii; Tremolada and Erba, 2002) were observed within this lower member about $15 \mathrm{~m}$ above the ferruginous surface (Aguado et al., 1999). The middle member of the Almadich Formation is mainly composed of black shales and marls and its base coincides with the FO of the planktonic foraminifer Schackoina cabri. The FO of E. floralis has been recorded near the base of the marly limestones and grey marls characterizing the upper member of the Almadich Formation.

The ${ }^{13} \mathrm{C}_{\text {carb }}$ profile shows a clear pattern, with the same general trends observed in the La Frontera and Carbonero sections, with two prominent positive excursions separated by a negative shift. The lowest part of the curve is poorly documented, as it is represented by only two analyses, with a lowest value of $1.4 \%$, and is capped by a discontinuity at the Barremian-Aptian boundary. The first positive excursion, with a maximum value of $2.7 \%$, is recorded within the Deshayesites weissi ammonite biozone (Fig. 4), predating the onset of the 'nannoconid crisis'. The subsequent negative excursion attains a minimum value of $0.4 \%$ in the uppermost part of the $H$. irregularis calcareous nannofossil biozone (equivalent to $G$. blowi planktonic foraminiferal biozone). The upper positive excursion, occurring in the Deshayesites deshayesi and Dufrenoyia furcata ammonite biozones, spans over $50 \mathrm{~m}$ and achieves a maximum value of $3.7 \%$ (Fig. 4). The ${ }^{13} \mathrm{C}_{\text {org }}$ record parallels that of the ${ }^{13} \mathrm{C}_{\mathrm{carb}}$, but with a lower sharpness (Fig. 4). de Gea et al. (2003) proposed a C-isotope stratigraphy, correlated with biostratigraphy published in Aguado et al. (1999), in which they recognized the eight segments first proposed by Menegatti et al. (1998) (Fig. 4). Although the C-isotope curve does not have a high-resolution, and some uncertainty in the segment boundaries can be acknowledged, the C3-C4 boundary, in the uppermost part of $B$. blowi biozone, is located at the base of the organic-rich interval, which records the main positive excursion.

\subsubsection{Puentenansa section}

The studied interval in the Puentenansa section corresponds to the Patrocinio Formation, which consists, in this section, of a $31 \mathrm{~m}$ thick succession of open marine argillaceous and silty marls overlying a $13 \mathrm{~m}$ thick unit of rudist, gastropod and coral limestones and orbitolinid marls. The contact between the two units is an unconformity represented by a dissolution surface coated by a thin ferruginous crust, suggesting a brief episode of emersion at the top of the limestone followed by a flooding surface. Above this surface, deposition of the marls of the Patrocinio Formation occurred as consequence of platform drowning as the result of a combined action of a relative sea-level rise and poisoning by siliciclastic (Najarro et al., 2011a). According to the study of nannofossil assemblages in the studied section, the first $22 \mathrm{~m}$ of the Patrocinio Formation belong to the upper half of the $H$. irregularis Zone, and the absence of narrow canal nannoconids has allowed the identification of the "nannoconid crisis" within this interval (Najarro et al., 2011b). The FO of E. floralis is registered $5 \mathrm{~m}$ above the sample PN-9 (Fig. 4). This biostratigraphic event allows the assignment of the upper part of the Patrocinio Formation in the Puentenansa section to the $R$ angustus Zone, suggesting the existence of a stratigraphic gap affecting to the upper part of the Lower Aptian (Najarro et al., 2011b).

In this section the ${ }^{13} \mathrm{C}_{\text {carb }}$ record can be subdivided into three successive intervals (Najarro et al., 2011a), (Fig. 4). The basal interval coincides with the Rábago and Umbrera Formations. It shows relatively homogeneous and positive ${ }^{13} \mathrm{C}$ values in the Rábago Formation (mean of $+2.2 \%$ ), and a significant and progressive decrease of about $1 \%$ through the Umbrera Formation (but still with positive values). The second interval of the ${ }^{13} \mathrm{C}$ curve correlates with the Patrocinio Formation. This interval is characterized by a notable negative excursion from values of $-0.4 \%$ a the base of the interval to $-4.5 \%$ at the top. This negative excursion is not gradual but punctuated by three negative peaks $(-2.9 \%,-4.1 \%$ and $-4.5 \%$ respectively; Fig. 4). Finally, the third interval in the ${ }^{13} \mathrm{C}_{\text {carb }}$ record shows the return to positive values, corresponding to the Reocin Formation. The carbon isotope composition of the bulk organic matter measured across the Patrocinio Formation in the Puentenansa section $\left({ }^{13} \mathrm{C}_{\mathrm{org}}\right.$ in Fig. 4) ranges between $-21.2 \%$ and $-25.2 \%$, and shows three prominent negative spikes. From the bottom, the C-isotope curve starts with values of $-22.2 \%$ and decreases sharply to $-24.8 \%$, resulting in a first negative excursion of $2.6 \%$ in magnitude. This is followed by a return to more positive values $(-21.6 \%)$. The subsequent ${ }^{13} \mathrm{C}_{\text {org }}$ values show a gradual decrease towards lower values, reaching a minimum of $-25.2 \%$ (second negative spike of $3.5 \%$ in 
magnitude). Then, the values become progressively higher up to values of $-22.6 \%$. Finally, at the top of the Patrocinio Formation, the profile displays a third negative spike of $-24.6 \%$ ( $~ 2 \%$ in magnitude) above the hiatal unconformity (Fig. 4).

The $\delta^{13} C_{\text {carb }}$ and $8^{13} C_{\text {org }}$ profiles lack the $C 4$ to $C 7$ isotopic segments of Menegatti et aL (1998), due to a discontinuity (Fig. 4) (Najarro et al., 2011b). Therefore, in the Puentenansa section only segment C3 of the OAE1 a was recorded (Fig. 4). This section differs from the sections studied in the SIPM mainly due to the presence of shallow water carbonates at the base of the Aptian and in the Upper Aptian (Fig. 4).

\subsection{Elemental geochemistry}

The TOC contents across all four sections vary between $0.5 \%$ and $5.6 \%$ (Table 1). Higher TOC contents occur in Carbonero and La Frontera sediments (average $\mathrm{TOC}=3.8 \%$ and $1.9 \%$, respectively), whereas Cau and Puentenansa sediments have lower TOC contents (average $\mathrm{TOC}=1.0 \%$ and $0.6 \%$ respectively). Sulphur is absent or present in only trace concentrations in La Frontera and Cau, whereas it is present in low concentrations in the other sections (Puentenansa average $S=0.1 \%$ and Carbonero average $S=0.22 \%$ ). Major element distributions (Table 1) clearly differentiate the four sections: Cau samples are marls and Puentenansa are mudstones, whereas Carbonero and La Frontera samples present a higher variability related to the facies differentiation between marls, mudstones and radiolarian marls.

\subsection{Distributions of hydrocarbon biomarkers}

The extractable hydrocarbons are dominated primarily by n-alkanes, acyclic isoprenoids, steranes and hopanes (Fig. 5), although some sections also contain strong low-molecular-weight (Cau) or highmolecular-weight (Carbonero) unresolved complex mixtures (UCM). n-Alkanes are saturated straight-chain compounds (Fig. 5), mainly derived from vascular plants, both from aquatic (short-chain) and terrestrial (long-chain) environments (e.g. Meyers, 1997); however, attributing a specific source to any $n$-alkanes in the more thermally mature settings (see below) is problematic due to catagenetic alterations. Acyclic isoprenoids are composed of polymerized isoprene units, and the dominant compounds identified here, pristane and phytane, are typically considered to be derived from chlorophyll (e.g. Powell and MoKirdy, 1973; but see ten Haven et al., 1987). Hopanes are $C_{27}-C_{35}$ pentacyclic triterpenoids and originate from bacterial bacteriohopanepolyols (Ourisson et al., 1982). Steranes are tetracyclic riterpanes arising from diagenetic alteration of sterols and consequently almost exclusively derive fromeukaryoticorganisms (e.g. Moldovan et al., 1985). In most samples, the n-alkanes, acyclic isoprenoids and hopanes dominate, with variable ratios of $n$-alkanes/hopanes, and steroids represent a lower contribution (Fig. 5).

\subsection{1. n-Alkanes}

The $n$-allsanes are present and typically the dominant compounds in most chromatograms. Short and long-chain $n$-alkanes are present, ranging from $n-C_{13}$ up to $n-C_{35}$ (Fig. 5), in all samples, but the distribution varies significantly among the samples studied, both between different sections and stratigraphically. In the Puentenansa and La Frontera sections there is a clear and strong bimodal distribution, represented by low-molecular-weight ( $\mathrm{MW} ;<\mathrm{C}_{22}$ ) components with no carbon preference and high-molecular-weight-components (HMW: $>\mathrm{C}_{24}$ ) that have an odd-over-even carbon number predominance (OEP) at La Frontera but not at Puentenansa (Fig. 6). In contrast, all of the Carbonero rocks samples are dominated by short-chain compounds and the HMW components have no carbon number preference. Somewhat intermediate distributions occur in the Cau samples.
Table 1

TOC, and elemental composition of selected samples.

\begin{tabular}{|c|c|c|c|c|c|c|c|c|}
\hline Sample & $\begin{array}{l}\text { Thickness } \\
\text { (m) }\end{array}$ & $\begin{array}{l}\text { TOC } \\
\%\end{array}$ & $\mathrm{~N} \%$ & $\mathrm{C \%}$ & $S \%$ & $\mathrm{Al}_{2} \mathrm{O}_{3} \%$ & $\mathrm{SiO}_{2} \%$ & $\mathrm{CaO} \%$ \\
\hline \multicolumn{9}{|c|}{ La Fronter } \\
\hline XF-103.1 & 43.25 & 1.1 & 0.0467 & 3.9193 & 0 & & & \\
\hline XF-96.2 & 26.90 & 1.4 & 0.0478 & 3.8031 & 0 & & & \\
\hline$X F-1-33$ & 25.7 & 0.7 & 0.0612 & 0.5714 & 0 & & & \\
\hline$X F-1-27$ & 24.5 & 0.8 & 0.063 & 0.6515 & 0 & & & \\
\hline$X F-1-23$ & 23.4 & 1.7 & 0.0945 & 1.3781 & 0.0397 & & & \\
\hline$X F-1-20$ & & & & & & 13.89 & 59.19 & 0.78 \\
\hline$X F-1-13$ & & & & & & 13.26 & 58.35 & 1.04 \\
\hline XF-1-1 & & & & & & 9.47 & 29.8 & 23.98 \\
\hline XF-90.16 & 22.20 & 4.5 & 0.0296 & 6.7333 & 0 & 6.05 & 26.35 & 29.83 \\
\hline XF-90.5 & 20.00 & 0.7 & 0.0318 & 6.0533 & 0 & 7.49 & 27.24 & 27.61 \\
\hline$X F-79$ & 13.50 & 4.1 & 0.0418 & 5.517 & 0 & & & \\
\hline $\mathrm{XF}-72$ & 9.30 & 4.8 & 0.0683 & 7.2018 & 0 & & & \\
\hline \multicolumn{9}{|c|}{ Puentenansa } \\
\hline PN-14 & 29 & 0.5 & 0.0513 & 0.1489 & 0.0014 & 20.89 & 46.66 & 0.33 \\
\hline $\mathrm{PN}-13$ & 27 & 0.8 & 0.0439 & 0.3525 & 0.0112 & 20.02 & 46.83 & 0.84 \\
\hline PN-10 & 21 & 0.6 & 0.0473 & 0.6973 & 0.0092 & 19.81 & 48.54 & 1.81 \\
\hline PN-7 & 15 & 0.6 & 0.0431 & 0.5447 & 0.2433 & & & \\
\hline PN-5 & 11 & 0.9 & 0.0418 & 1.1211 & 0.1706 & & & \\
\hline PN-4 & 9 & 0.7 & 0.0443 & 0.7718 & 0.1178 & & & \\
\hline PN-3 & 7 & 0.4 & 0.0275 & 3.7348 & 0.0123 & & & \\
\hline PN-2 & 5 & 0.6 & 0.0425 & 1.216 & 0.2702 & & & \\
\hline PN-1 & 3 & 0.5 & 0.0436 & 1.4614 & 0.292 & & & \\
\hline \multicolumn{9}{|l|}{ Cau } \\
\hline Cau-32a & 88.3 & 0.9 & & & & 8.14 & 16.55 & 37.12 \\
\hline Cau28a & 60.6 & 0.7 & 0.0225 & 9.8446 & 0 & 5.57 & 113 & 42.69 \\
\hline Caџ23a & 52.5 & 1.9 & 0.0338 & 9.3192 & 0.006 & 7.09 & 14.24 & 39.12 \\
\hline Caษ20a & 46 & 1 & 0.0305 & 9.4636 & 0.0071 & & & \\
\hline Cau19a & 42 & 0.9 & 0.0279 & 9.2777 & 0.01 & 5.48 & 12.5 & 41.06 \\
\hline Cau16a & 37.1 & 1 & 0.0337 & 8.6089 & 0.0369 & 6.98 & 16.84 & 36.76 \\
\hline Cau13a & 33.6 & 0.8 & 0.0213 & 8.2714 & 0.0138 & 7.57 & 17.99 & 35.94 \\
\hline Cau12a & 29.5 & 1.1 & 0.1051 & 0.9445 & 0.0846 & & & \\
\hline Cau10a & 25.1 & 0.9 & 0.0192 & 9.2012 & 0 & & & \\
\hline \multicolumn{9}{|l|}{ Carbonero } \\
\hline $\mathrm{CAB}-7$ & 63.6 & 4.2 & 0.15 & 5.8234 & 0.1344 & & & \\
\hline CAB- 6 & 53 & 5.6 & 0.18 & 5.3984 & 0.1254 & & & \\
\hline CAB-5 & 51 & 4.8 & 0.14 & 5.3118 & 0.7261 & 9.8 & 52.16 & 8.66 \\
\hline CAB-4 & 51 & 1.1 & 0.08 & 0.9067 & 0.2114 & 13.46 & 58.56 & 2.5 \\
\hline $\mathrm{CAB}-2 \mathrm{C}$ & 40 & 3.7 & 0.1 & 6.6046 & 0.2951 & 10.3 & 35.05 & 19.71 \\
\hline CAB- $2 A$ & 30.3 & 4.2 & 0.09 & 3.5869 & 0.0303 & 12.4 & 42.06 & 12.13 \\
\hline CAB-1J & 25 & 3 & 0.0579 & 4.8499 & 0.0514 & 10.2 & 33.96 & 20.63 \\
\hline
\end{tabular}

To facilitate interpretation of these $n$-alkane distributions, we have calculated two different ratios (Fig. 6): the HMW/MWW ratio ([n- $\mathrm{C}_{25}+$ $\left.\left.n-C_{26}+n-C_{27}+n-C_{28}+n-C_{29}\right] /\left[n-C_{17}+n-C_{18}+n-C_{19}+n-C_{20}+n-C_{21}\right]\right)$ in order to constrain the relationship between long and short-chain compounds, and also the odd-over-even predominance ratio (OEP1 $=$ $\mathrm{C}_{21}+\left(6 \times \mathrm{C}_{23}\right)+\mathrm{C}_{25} /\left(4 \times \mathrm{C}_{22}\right)+\left(4 \times \mathrm{C}_{24}\right)$, and $\mathrm{OEP} 2=\mathrm{C}_{25}+\left(6 \times \mathrm{C}_{27}\right)+$ $\left.C_{29} /\left(4 \times C_{26}\right)+\left(4 \times C_{28}\right)\right)$, defined by Scalan and Smith (1970). We note that the HMW/IMW ratio has also been presented as the Terrestrial to Aquatic Ratio (TAR; Bourbonniere and Meyers, 1996), but the TAR terminology is not used in this context because of the prominent control of thernal maturity on calculated ratios (see below). There is a clear OEP (Table 2 and Fig. 6) in all of the La Frontera and Cau samples (OEP1 =1.07-1.73; OEP2 $=1.75-3.49)$, but it is low or absent in the Puentenansa and Carbonero samples (PN: OEP1 $=1.37-1.53$; OEP2 = 0.60-1.59; СAB: OEP1 =0.71-1.35; OEP2 =0.84-1.41; Table 2). Similarly, all Carbonero samples are characterized by a dominance of shortchain n-alkanes (average HMW/LMW ratios of $0.62 \pm 0.36$ ). HMW/ INW ratios at Puentenansa are similar to those at Carbonero $(0.69 \pm$ 0.47), but the distribution is different, as it is bimodal (see Fig. 5). In the other sections, the HMW $n$-alkanes are proportionally more abundant (HMW/LMW ratios at La Frontera $=0.83 \pm 0.61$ and Cau $=1.33 \pm$ $0.17)$. With respect to ver ical trends, we aclnowledge that we have limited data from each section; nonetheless, the CAB and CAU sections, with 




Fig. 5. Selected total ion chromatograms of samples from the studied sections. Numbers refer to $n$-alkanes.

greater sample resolution, show a clear variability trough the section in the HMW/IMW ratio (Fig. 6).

\subsubsection{Isoprenoids}

Pristane and phytane are abundant in all samples and exhibit high variability in their relative abundances. The $\mathrm{Pr} / \mathrm{Ph}$ and isoprenoid/ $n$-alkane ratios vary strongly, both between different sections and stratigraphically (Table 2 and $\mathrm{Fig} .6$ ). $\mathrm{Pr} / \mathrm{Ph}$ ratios are highest in the Carbonero $(\mathrm{Pr} / \mathrm{Ph}=2-4.65$, average $=2.98)$ and La Frontera samples $(\mathrm{Pr} / \mathrm{Ph}=2.08-4.6$, average $=3.4)$, have intermediate values in the Cau samples $(0.67-3.15$, average $=1.64)$ and have the lowest values in the Puentenansa samples (0.6-0.68). At the Cau and Carbonero sections where a more complete suite of samples has been analyzed, $\mathrm{Pr} / \mathrm{Ph}$ ratios generally decrease upsection, with highest values coinciding with pre-negative ${ }^{13} \mathrm{C}$ excursion levels. The isoprenoid/n-alkane ratios (Fig. 6) are also highly variable, with generally higher $\operatorname{Pr} / n-C_{17}$ ratios and lower $\mathrm{Ph} / n-\mathrm{C}_{18}$ ratios in the Carbonero Section than at Cau (Table 2 and Fig. 6).

\subsubsection{Hopanes}

Hopanes are present in all of the samples studied, ranging in carbon number from $C_{27}$ to $C_{35}$. The $C_{30}$ component is dominant in the Carbonero and La Frontera samples, $C_{31}$ is dominant or equivalent to $C_{30}$ in Cau samples, and the $C_{29}$ hopane is dominant in the Puentenansa section (Fig. 7). The $C_{31}-C_{35}$ extended hopanes (homohopanes) are present in $\mathrm{CAB}$ and $\mathrm{PN}$ samples, whereas in CAU and XF samples only $C_{31}-C_{32}$ compounds are present. The commonly observed decrease in hopane concentration from $C_{31}$ to $C_{35}$ occurs in all samples, except for PN-15, where the $C_{35}$ component is somewhat more abundant than the $\mathrm{C}_{34}$. Crucially, the distribution of hopane stereoisomers differs dramatically among the four sections (Fig. 7 and Table 3). The $22 \mathrm{~S} /(22 \mathrm{~S}+22 \mathrm{R})$ homohopane ratio is 0.5 in the Carbonero and Puentenansa samples, whereas in La Frontera and Cau this ratio is $0.13-0.37$. Similarly, the $17 \alpha, 21 \beta(\mathrm{H})$ isomers are dominant in the Carbonero and PN sections, with subordinate abundances of the $17 \%, 21 \alpha(\mathrm{H})$ diastereomers (moretanes), whereas the Cau samples are characterized by a dominance of hopane diastereomers with the $17 \%, 21 \beta(H)$ configuration, although $17 \alpha, 21 \beta(H)$ and $17,21 \alpha(\mathrm{H})$ diasteromers are also present. The Ts and $T m C_{27}$ hopane diastereomers are present in all samples, with a $\mathrm{Tm} / \mathrm{Ts}$ ratio $\geq 1$ in the Carbonero, La Frontera and Cau samples and a Tm/Ts ratio $<0.4$ in Puentenansa samples.

Gammacerane is present only in the Puentenansa samples (confirmed with standard co-injection), where this compound has a relatively high abundance in comparison with hopanes $\left(\mathrm{G} / \mathrm{C}_{30}=0.58\right)$.

\subsubsection{Steranes}

A range of $C_{27}$ to $C_{30}$ steranes occur in all of the sections studied (Fig. 8); in a broad sense, the relative distributions are similar, with $C_{29}$ always being dominant (48\%-70\%), $C_{27}$ intermediate (19\%-28\%), and $C_{28}$ minor $(9 \%-31 \%)$, but considerable variability within that framework is present. Further variability is reflected by the abundance of a $C_{30}$ 4-methylsterane, tentatively interpreted to be dinosterane on the basis of its mass spectrum and retention time (Summons et al., 1987), which is present in some XF and CAU samples but is absent or occurs in only trace abundances in the PN and Carbonero samples. In fact, in one sample (Cau-24, see Fig. 8), it is one of the dominant compounds in the apolar fraction and certainly the most abundant sterane.

The sections also differ with respect to the relative abundances of sterane diastereomers. The CAU and XF samples are represented almost exclusively by the $5 \alpha(\mathrm{H}), 14 \alpha(\mathrm{H}), 17 \alpha(\mathrm{H}), 20 \mathrm{R}$ epimer. On the other hand, in $C A B$ and $\mathrm{PN}$ samples, $5 \alpha(\mathrm{H}), 14 \boldsymbol{( H )}, 17 \boldsymbol{( H )}$ diastereomers and $22 S$ steranes are also relatively abundant, with similar 

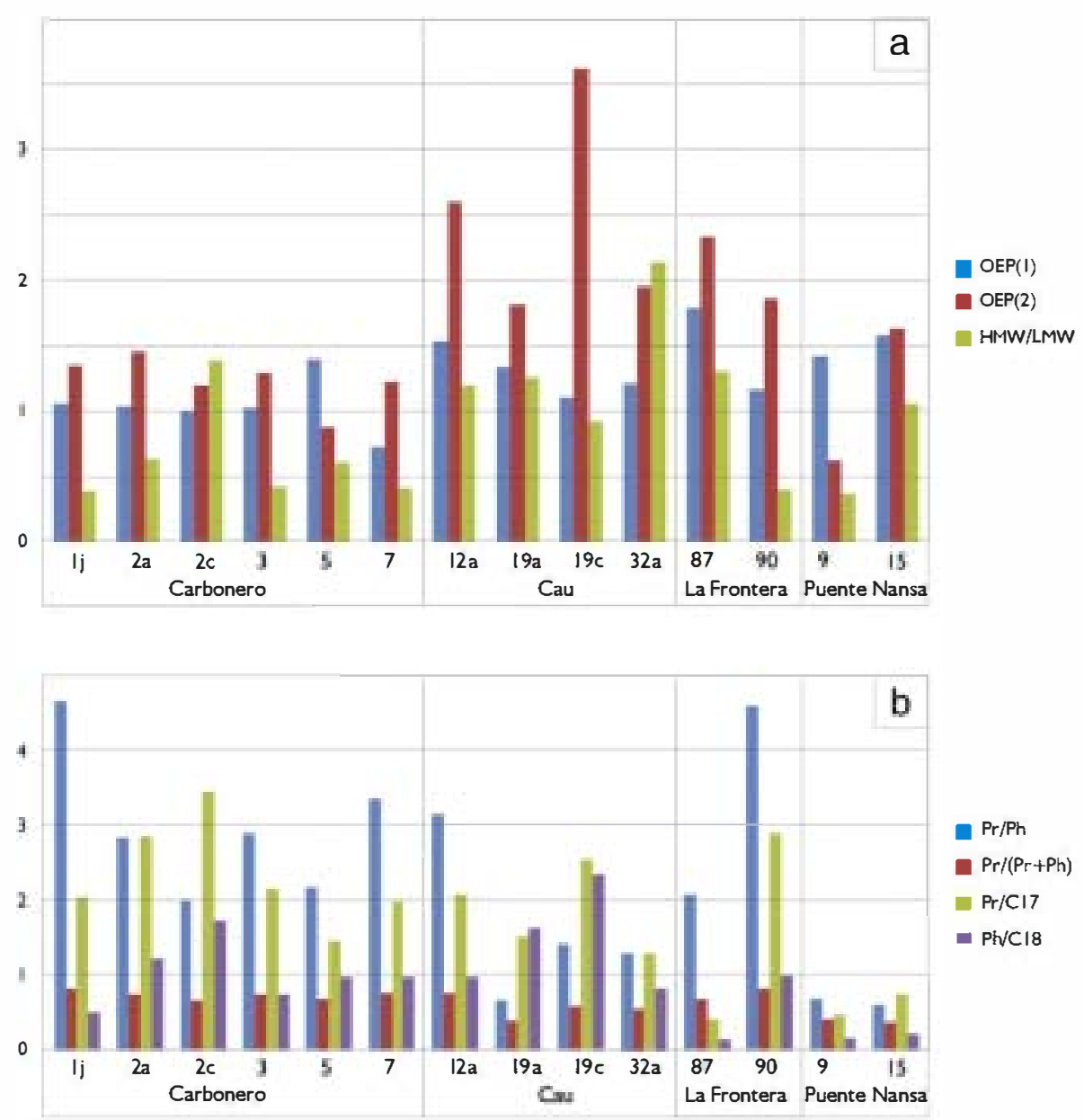

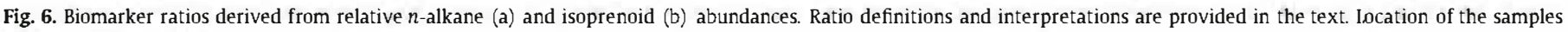
shown in Figs. 3 and 4.

relative distributions in both sections (Fig. 8). Furthermore, the ratios of the $20 \mathrm{~S}$ and $20 \mathrm{R}$ epimers differ between the latter two sections, with the 20S/20R ratio being around 1 for the $5 \alpha(H), 14 \alpha(H)$, $17 \alpha(\mathrm{H})$ diastereomer in $\mathrm{CAB}$ samples, whereas in PN samples the

Table 2

n-Alkanes and isoprenoids ratios.

\begin{tabular}{|c|c|c|c|c|c|c|c|}
\hline Sample & $\mathrm{Pr} / \mathrm{Ph}$ & $\mathrm{Pr} /(\mathrm{Pr}+\mathrm{Ph})$ & $\mathrm{Pr} / \mathrm{C} 17$ & $\mathrm{Ph} / \mathrm{C} 18$ & $\begin{array}{l}\text { OEP } \\
(1)\end{array}$ & $\begin{array}{l}\text { OEP } \\
(2)\end{array}$ & HMW/LMW \\
\hline \multicolumn{8}{|l|}{ Carbonero } \\
\hline $\mathrm{CAB}-1 \mathrm{~J}$ & 4.65 & 0.82 & 2.05 & 0.51 & 1.02 & 1.30 & 0.38 \\
\hline CAB- $2 A$ & 2.84 & 0.74 & 2.86 & 1.23 & 1.00 & 1.41 & 0.62 \\
\hline $\mathrm{CAB}-2 \mathrm{C}$ & 2.00 & 0.67 & 3.46 & 1.73 & 0.98 & 1.17 & 1.34 \\
\hline CAB-3 & 2.89 & 0.74 & 2.15 & 0.75 & 0.99 & 1.25 & 0.42 \\
\hline CAB-5 & 2.18 & 0.69 & 1.45 & 0.97 & 1.35 & 0.84 & 0.60 \\
\hline $\mathrm{CAB}-7$ & 3.36 & 0.77 & 1.98 & 0.98 & 0.71 & 1.18 & 0.34 \\
\hline \multicolumn{8}{|l|}{ Cau } \\
\hline CAU-12a & 3.15 & 0.76 & 2.07 & 0.97 & 1.49 & 2.51 & 1.16 \\
\hline CAU-19a & 0.67 & 0.40 & 1.52 & 1.63 & 1.29 & 1.75 & 1.22 \\
\hline CAU-19C & 1.42 & 0.59 & 2.54 & 2.34 & 1.07 & 3.49 & 0.90 \\
\hline CAU- 32 a & 1.32 & 0.57 & 1.30 & 0.84 & 1.17 & 1.88 & 2.06 \\
\hline \multicolumn{8}{|l|}{ La Frontera } \\
\hline$X F-87$ & 2.08 & 0.68 & 0.41 & 0.14 & 1.73 & 2.25 & 1.26 \\
\hline XF-90 & 4.60 & 0.82 & 2.90 & 0.99 & 1.12 & 1.80 & 0.39 \\
\hline \multicolumn{8}{|c|}{ Fuentenans } \\
\hline $\mathrm{PN}-9$ & 0.68 & 0.41 & 0.46 & 0.16 & 1.37 & 0.60 & 0.36 \\
\hline PN-15 & 0.60 & 0.38 & 0.75 & 0.22 & 1.53 & 3.00 & 1.02 \\
\hline
\end{tabular}

20R stereochemistry is dominant. Similarly, $13 \boldsymbol{\beta}, 17 \alpha$ steranes (diasteranes) are relatively abundant compared to regular steranes in all of the Carbonero samples but absent in the other sections.

\section{Discussion}

5.1. Correlation of $\mathrm{C}$-isotope curves and integration with biostratigraphic data and distribution of organic-rich facies

To correlate the four sections, we have used the biostratigraphic data and also attempted to identify the eight segments proposed by Menegatti et al. (1998) for the Aptian C-isotope profile from the "Selli level" in the Alps. Those authors proposed a subdivision of the Aptian C-isotopic record in 8 segments based on changes observed in two different sections in the Alpine domain and attempted to correlate those carbon isotopic temporal variations with nannofossils and planktonic foraminifers biozonations (Fig. 9). The Cau and La Frontera sections both contain the eight segments described by Menegatti et al. (1998), whereas in the Carbonero section there are no isotope data for the $\mathrm{C} 1$ segment, although biostratigraphic data suggest it is present. In Puentenansa, the succession starts within the $\mathrm{C} 2$ segment, and there is a discontinuity affecting the $\mathrm{C} 4$ to $\mathrm{C} 7$ segments (see Figs. 3, 4 and 9).

The sections exhibit the expected correlations between the biostratigraphic data and the C-isotope curves (i.e. segments proposed by Menegatti et al., 1998), and consistent relationships are observed in all four Iberian sections studied with the exception of the FO of E. floralis. This datum was recorded within the C6 segment in La 

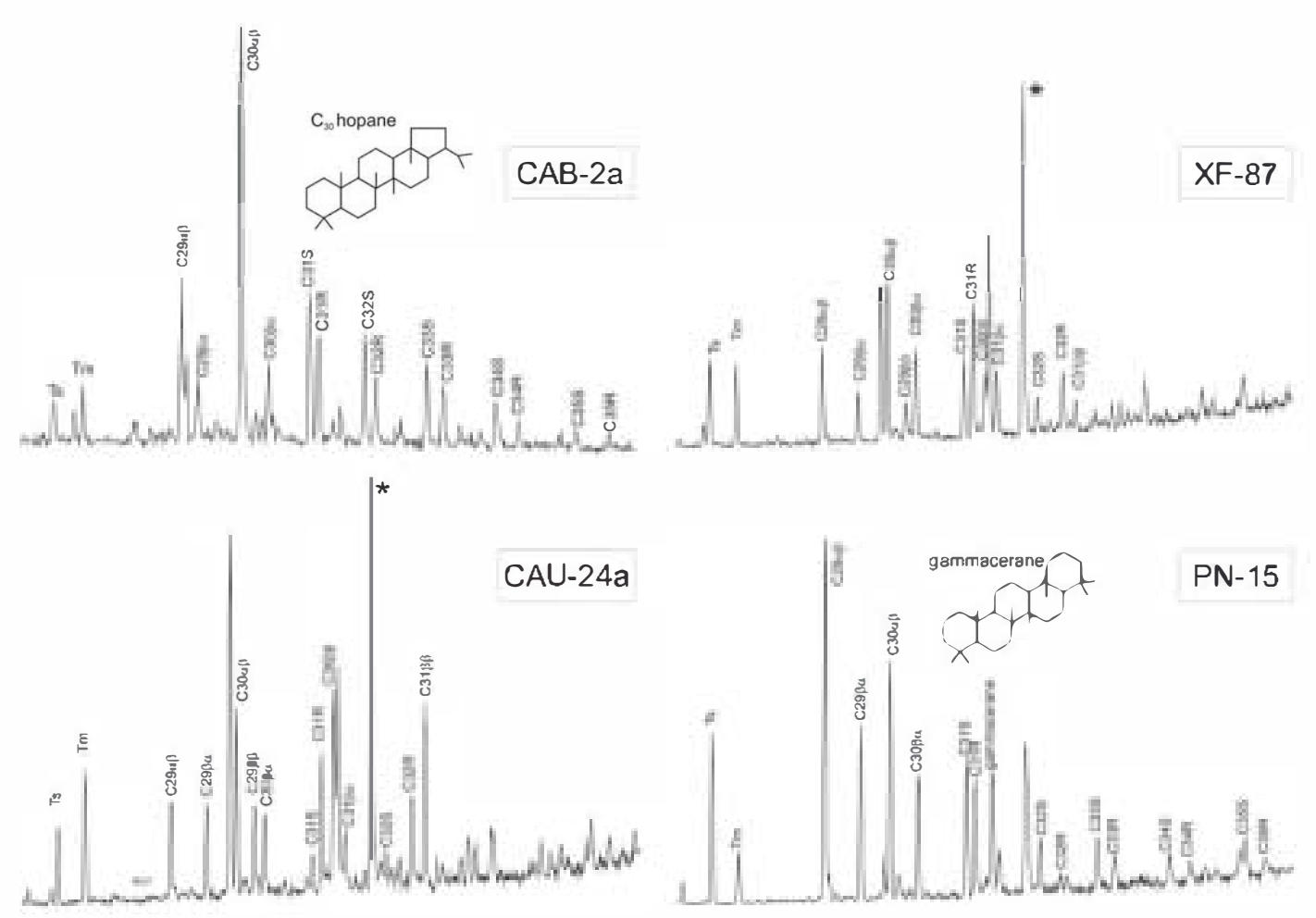

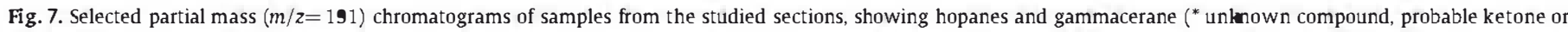
diahopane).

Frontera section, and within the $\mathrm{C} 7$ segment in Carbonero and Cau sections. We suspect that the diachronism in the record of the FO of E. floralis in Carbonero section is related to the poor preservation of the nannofossil assemblages in the middle member and lowest part of the upper member of the Carbonero Formation. In most of the samples from this middle member, nannofossils were not found or were very poorly preserved.

In the Cau section, however, the cause of this diachronism cannot be attributed to preservation, as nannofossil assemblages are diverse and moderately well preserved in this interval, and we suspect that it is probably related to palaeoecological factors. The palaeoceanographic setting of the Cau section was more proximal and shallower (outer platform) than that of the La Frontera section (pelagic). In addition, the

Table 3

Maturity-related biomarker parameters (ratios of hopanes and steranes).

\begin{tabular}{|c|c|c|c|c|c|}
\hline \multirow[b]{2}{*}{ Sample } & \multicolumn{2}{|l|}{ Hopanes } & \multirow[b]{2}{*}{ Sample } & \multicolumn{2}{|l|}{ Steranes } \\
\hline & $\begin{array}{l}22 S / \\
(22 S+22 R) \\
(\mathrm{C} 31)\end{array}$ & $\begin{array}{l}\mathrm{C} 30 \mathbf{\beta} \boldsymbol{\alpha} / \\
(\mathbf{\beta} \boldsymbol{\alpha}+\boldsymbol{\alpha} \beta)\end{array}$ & & $\mathbf{B \beta} / \mathbf{\beta} \mathbf{\beta}+\alpha$ & $\begin{array}{l}20 S / \\
(20 S+20 R)\end{array}$ \\
\hline \multicolumn{3}{|l|}{ Carbonero } & \multicolumn{3}{|c|}{ Carbonero } \\
\hline $\mathrm{CAB}-7$ & 0.53213368 & 0.14231738 & $\mathrm{CAB}-7$ & 0.302463054 & 0.516723549 \\
\hline CAB6a & 0.54291845 & 0.11111111 & CAB-5 & 0.34566787 & 0.4665195 \\
\hline CAB-5 & 0.54736842 & 0.13127413 & $\mathrm{CAB}-3$ & 0.44603033 & 0.432876712 \\
\hline CAB-3a & 0.54174397 & 0.13378685 & $\mathrm{CAB}-2 \mathrm{C}$ & 0.399749373 & 0.505675955 \\
\hline $\mathrm{CAB}-2 \mathrm{a}$ & 0.56915739 & 0.172322023 & $\mathrm{CAB}-2 \mathrm{~A}$ & 0.371191136 & 0.512352309 \\
\hline CAB-1J & 0.54363636 & 0.18592297 & CAB-1J & 0.331963001 & 0.492583919 \\
\hline \multicolumn{3}{|c|}{ La Frontera } & \multicolumn{3}{|c|}{ Puentenansa } \\
\hline $\mathrm{XF}-90$ & 0.22988506 & 0,33174603 & PN-15 & 0.466313763 & 0.434472208 \\
\hline$X F-87$ & 0.37260274 & 0,38235294 & & & \\
\hline \multicolumn{6}{|l|}{ Cau } \\
\hline CAU-32A & 0.131528046 & 0.581020591 & & & \\
\hline CAU-24a & 0.21507761 & 0.32028986 & & & \\
\hline CAU-19a & 0.225 & 0.32484076 & & & \\
\hline \multicolumn{6}{|c|}{ Puentenansa } \\
\hline $\mathrm{PN}-15$ & 0.52012384 & 0.32767402 & & & \\
\hline $\mathrm{PN}-9$ & 0.50875146 & 0.42937063 & & & \\
\hline
\end{tabular}

nannofossil assemblages from this interval in the Cau section contain higher proportions of nannoconids and pentaliths (Braarudosphaera, Micrantholithus) than those of the La Frontera section. Nannoconids are well-documented Cretaceous taxa predominantly associated to low-latitude carbonate-shelfal and epicontinental basins likely with stratified waters (Thierstein, 1976; Roth and Bowdler, 1981; Roth and Krumbach, 1986; Busson and Noël, 1991; Mutterlose, 1992; Street and Bown, 2000; Bown, 2005). They are also related to oligotrophic surface waters in which salinity may also have played a significant control (lees et al., 2005). Erba (1994) suggested that nannoconids were analogous to the extant genus Florisphaera, which proliferates in the deep photic zone of modem oceans at a deep nutricline. This author suggested that the OAE1a-related nannoconid crisis was the result of nutrification of surface-waters, triggering blooms of surface waters coccolithophorids and depletion of deeper-dwelling nannoconids. Pentaliths (Micrantholithus and Braarudosphaera) appear to be similarly neritic to nannoconids in distribution. Its ecology is also probably related to neritic factors such as reduced salinity and enhanced nutrient content (Roth and Bowdler, 1981; Parker et al., 1985; Siesser et al., 1992; Street and Bown, 2000; Bown, 2005). Micrantholithus was replaced by Braarudosphaera in the Aptian, which appears to have retained a similar ecology from Aptian to recent times, being most common in neritic environments (Gran and Braarud, 1935). Other anomalous occurrences of Braarudosphaera blooms, linked to post-extinction assemblages (Cretaceous-Tertiary boundary) or to subropical open-ocean sites (Parker et al., 1985; Scarparo-Cunha and Shimabukuro, 1997) suggest an opportunistic behavior for this taxon (Siesser et al., 1992). Given the paleoceanographic setting of the Cau section (distal part of a platform) and the above-mentioned higher abundances of ecologically significant nannoconids and pentaliths through the C6 and C7 carbonisotope intervals, we suggest that a shallower, more restricted environment, with lower salinity, could be related with the delay in the first record of $E$. floralis in this section. Similar diachronisms in the FOs and LOs of several micro- and nannofossil indicators with respect to the carbon-isotope stratigraphy have been also detected for sections in the Mazagan Plateau and the Vocontian Trough (Herrle et al, 2004), and 

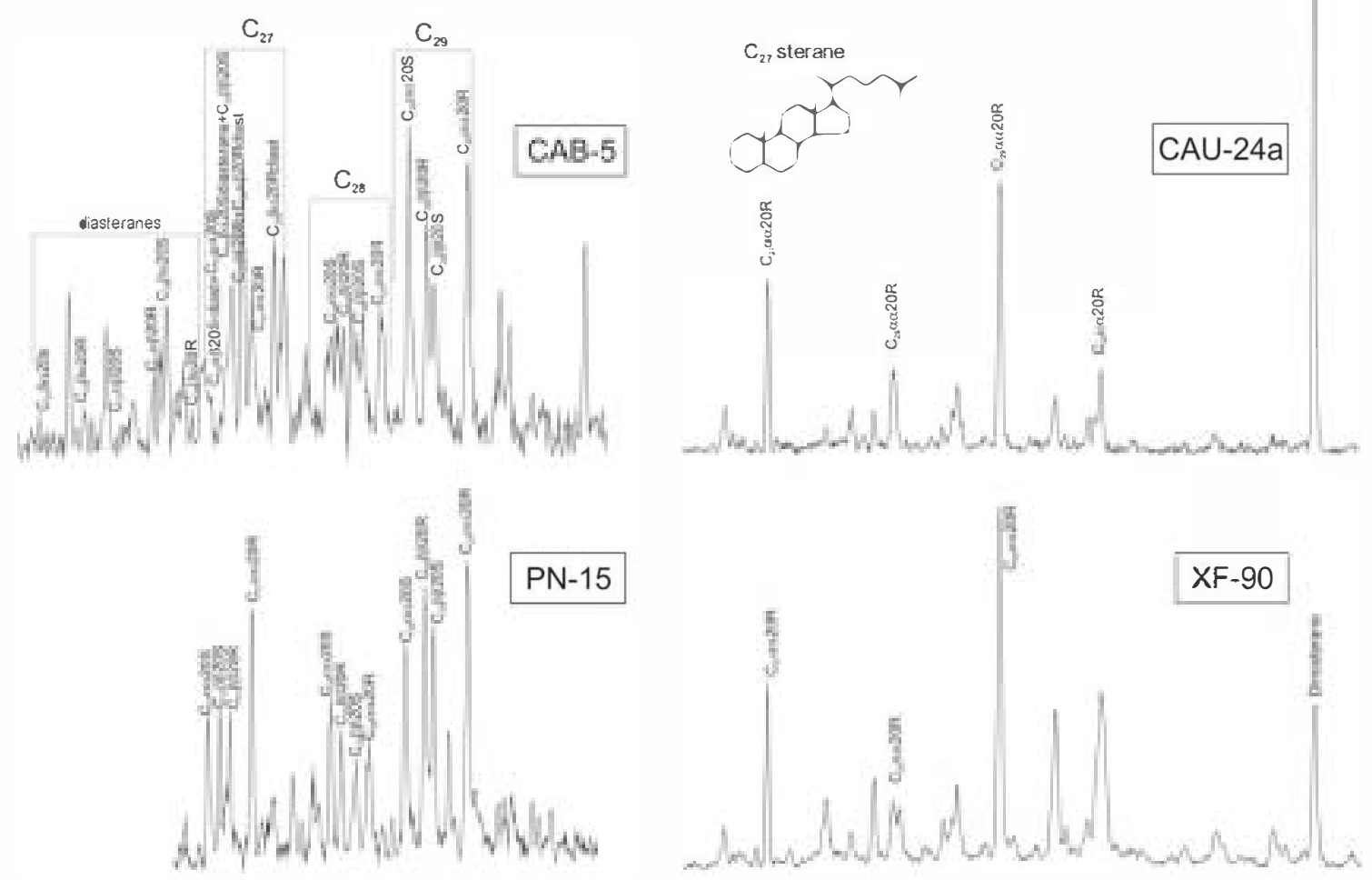

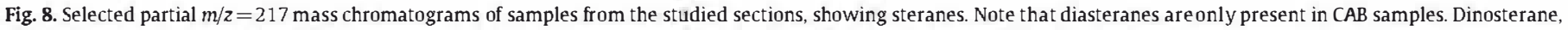
although present in these $m / z=217$ chromatograms, has a mass spectrum with a dominant 231 fragment and a minor $217 \mathrm{fragment}$.

interpreted in terms of regional differences in palaeoenvironmental conditions.

Taking this into account, the data presented in this study reveal several relationships, shown in Figs. 3 and 4: (1) The C1-C2 boundary is affected by a discontinuity, at the Barremian-Aptian boundary, in all four sections; (2) the $\mathrm{C} 3-\mathrm{C} 4$ boundary corresponds to the base of $S$. cabri foraminifer biozone; (3) the base of the $R$. angustus nannofossil biozone is diachronic, and its first occurrence lies within the C6 segment; and (4) the base of the G. ferreolensis foraminifer biozone occurs within the $\mathrm{C} 7$ segment.
Correlation of biostratigraphy, C-isotope stratigraphy and facies among the four sections reveals a variety of spatial and temporal relationships (Fig. 10). Although C-isotope stratigraphy is correlatable around the world, the timing of deposition of organic-rich sediments is not coeval (i.e. Jenkyns, 2010), and that is apparent in the Iberian region of the Tethys. Organic-rich facies are first deposited in pelagic environments (La Frontera and Carbonero sections), at the base of the Aptian and corresponding to the $\mathrm{C} 2$ segment of the carbon isotope profile, whereas organic-rich black shales or marls are deposited during the $\mathrm{C} 3$ or $\mathrm{C} 4$ segments in platform settings (Puentenansa and Cau
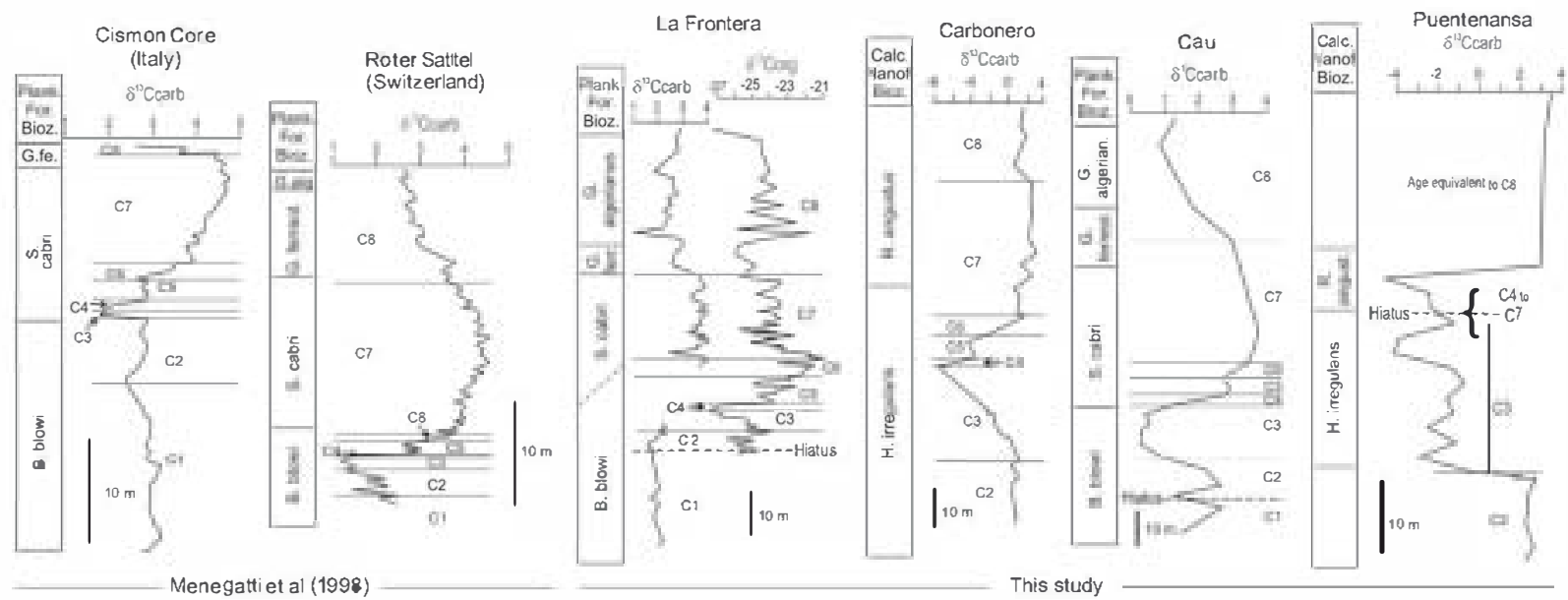

Fig. 9. Correlation of the studied sections with the reference curves of Menegatti et aI., 1998. 


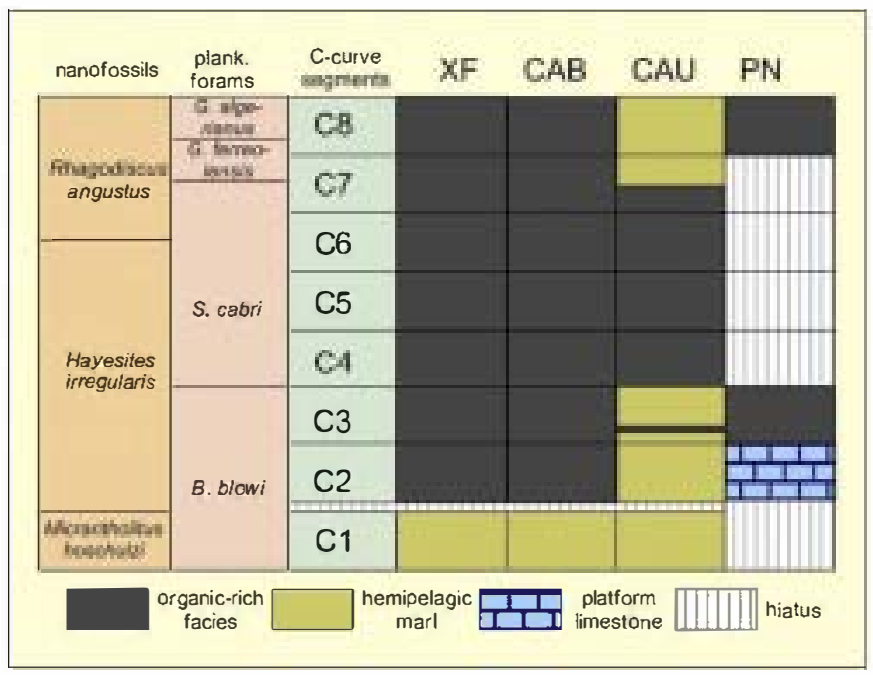

Fig. 10. Correlation between C-isotope stratigraphy (segments from Menegatti et al., 1998), biostratigraphy and facies.

sections, respectively). Also, the interval of deposition of black shales is longer in pelagic sections (up to the $\mathrm{C} 8$ segment) than in the platform sections (C7) in the SIPM. When comparing the palaeogeographically distinct platform settings (SIPM, Cau, and NCB, Puentenansa), the deposition of organic-rich facies starts earlier and persists longer in the North Cantabrian basin ( $\mathrm{C}$ to $\mathrm{C} 8$ ) than in the South Iberian ( $\mathrm{C}$ to “early" C7).


Fig. 11. Maturity-related biomarker parameters. a: $22 S /(22 S+22 R)$ homohopane ratios versus $\boldsymbol{\beta} \boldsymbol{\alpha} /(\mathbf{\beta} \boldsymbol{\alpha}+\boldsymbol{\alpha})$ hopane ratios. b: $\mathbf{\beta \beta} /(\mathbf{\beta} \mathbf{\beta}+\boldsymbol{\omega})$ sterane ratios versus $20 \mathrm{~S} /$ $(20 \mathrm{~S}+20 \mathrm{R})$ sterane ratios.

\subsection{Organic geochemistry}

\subsubsection{Thermal maturity}

The use of biomarker distributions to assess the thermal maturity of organic matter in sediments and rocks is well established (e.g. Peters et al., 2005). The most powerful tools at low to moderate maturity (with respect to oil generation) are those based on the relative distribution of sterane and hopane isomers, and that is the focus here. However, thermal maturity also affects $n$-alkane distributions and, therefore, informs our interpretation of between-section differences in those parameters.

The Carbonero section has $22 \mathrm{~S} /(22 \mathrm{~S}+22 \mathrm{R})$ homohopane ratios of ca 0.55, C30 $\beta \alpha /(\boldsymbol{\beta} \alpha+\alpha \boldsymbol{\beta})$ hopane ratios of ca 0.15 (Fig. 11a), $\beta \boldsymbol{\beta} /$ $(\boldsymbol{\beta} \beta+\alpha \alpha)$ sterane ratios of 0.37 , and $20 S /(20 S+20 R)$ sterane ratios of 0.49 (Table 3, Fig. 11b), and abundant diasteranes. All of these data indicate that $\mathrm{OM}$ from the Carbonero section is thermally mature with respect to oil generation (Mackenzie et al., 1980; Seifert and Moldowan, 1980; Waples and Machihara, 1991). Although the homohopane ratios are at a maximum and cannot put an upper limit on the section's thermal maturity, the persistence of these biomarkers-and especially the moretanes-suggests that the section has not exited the oil generation window. Sterane distributions also indicate that the section is near the peak stage of oil generation, equivalent to a vitrinite reflectance between 0.65 and 0.85 (according to Peters et al., 2005). The elevated thermal maturity accounts for the low HMW/LMW n-alkane ratios and the lack of an odd-over-even predominance.

The Cau and La Frontera sections, in contrast, are characterized by distributions consistent with low thermal maturity, including a dominance of $22 \mathrm{R}$ homohopanes (i.e. $22 \mathrm{~S} /(22 \mathrm{~S}+22 \mathrm{R})$ homohopane ratios of $0.13-0.37$ ), the persistence of hopanes with the biological and thermally unstable $17 \boldsymbol{\beta}, 21 \beta(\mathrm{H})$ configuration, steranes represented only by the $\alpha \alpha \alpha 20 \mathrm{R}$ isomers, and an absence of diasteranes (Table 3, Figs. 7 and 8). These data indicate that Cau and La Frontera have very low maturity and explain why higher plant wax $n$-alkane distributions, including the high OEP and HMW/LMW ratios, have persisted. Puentenansa samples have hopane and sterane ratios indicating that the OM is thermally mature (within the peak stage of oil generation) but not to the same degree as the Carbonero samples; for example, diasteranes are not present in Puentenansa. Thus, differences in thermal maturity are a main driver of organic geochemical differences among the studied sections. Specifically, Carbonero and Puentenansa OM is thermally mature, whereas Cau and La Frontera OM is thermally immature, probably with an equivalent vitrinite reflectance lower than 0.4 (according to Peters et al., 2005). Particularly interesting are the important differences observed between Carbonero and La Frontera OM, taking into account that they were deposited in nearby areas. The higher degree of maturation showed in Carbonero samples could be related to the Cretaceous tectonic and volcanic activity occurred in the Carbonero area, related to the extensional tectonics (Molina et al., 1998; de Gea et al., 2008a, 2008b) which could have resulted in a heating of the sediments, whereas the nearby La Frontera area, not affected by these processes, records immature OM; however, a different burial history cannot be dismissed. The low thermal maturity in Cau and La Frontera sections suggests that functionalized biological compounds, including alcohols and carboxylic acids, will be preserved in these sections (which we have confirmed but will be discussed in subsequent papers). This will affect interpretation of OM sources and sedimentary environments and is an important caveat to subsequent sections.

\subsubsection{OM sources and environmental conditions}

lipid biomarkers can be used to infer sources of organic matter (e.g. terrestrial vs marine) and depositional conditions (e.g. oxic vs. anoxic). Overall, all of the OM present in the studied samples is interpreted to derive from significant terrestrial inputs as well as 
marine and bacterial sources. The differences in thermal maturity complicate comparison of biomarker parameters among the sections. Moreover, the high level of maturity in several samples prevents an accurate interpretation in terms of source. Nevertheless, biomarker data from this study do reveal some systematic relationships, allowing tentative comparisons.

5.2.2.1. OM sources. The predominance of high molecular weight $n$-alkanes $\left(\mathrm{C}_{25}-\mathrm{C}_{35}\right)$ with an odd-over-even carbon number in the La Frontera and Cau sections indicate a terrestrial contribution from wax lipids of higher plants (Eglinton and Hamilton, 1967). The low molecular weight $\mathrm{C}_{14}-\mathrm{C}_{24} n$-alkanes, as well as pristane and phytane, from the same sections likely derive from marine contributions. Puentenansa samples have a slight OEP, but still contain a strong HMW n-alkane $\left(C_{25}-C_{35}\right)$ signal, which would also indicate a terrestrial contribution. The predominance of LMW $n$-alkanes in CAB samples reflects their thermal maturity rather than OM sources.

The steranes show a rather constant distribution with a dominance of $\mathrm{C}_{29}$ compounds in all samples. This feature could also indicate a strong terrestrial contribution (Huang and Meinschein, 1979), but caution is essential as many algae synthesize $C_{29}$ sterols (Peters et al., 2005 and references therein). Further evidence that the high $\% C_{29}$ steranes should be interpreted cautiously comes from the fact that there are no systematic differences between the platform and pelagic sections, even when comparing sections with similar thermal maturity. Marine inputs are clearly significant at all sites, despite the relatively low $\% \mathrm{C}_{27}$ and $\% \mathrm{C}_{28}$ values, indicated in particular by the occurrence of dinosterane derived from dinoflagellates (Withers, 1983). Dinosterane occurs in several samples in concentrations comparable to those of steranes (XF samples), is absent in others (CAB and PN samples, CAU-12, CAU-19a and CAU-19c), and is one of the most abundant hydrocarbons in CAU-24. Although the sample resolution is limited, there is strongvariation in dinosterane concentrations within a given section, indicating that dinoflagellate production varied, perhaps reflecting changes in nutrient status. Moreover, the particularly high concentration in the CAU-24 sample suggests that these conditions arose when either upwelling or runoff delivered nutrients to the shallow marine environment. However, insufficient data prevent us from further interpretation of either temporal rends or differences between sections.

Bacterial sources of OM are demonstrated by the presence of hopanes in all samples. Also, although it is not a bacterial compound, gammacerane typically occurs when bacteria are present in the water column (Sinninghé-Damsté et al., 1995; Peters et al., 2005). Intriguingly, the abundance of hopanes relative to n-alkanes is particularly high in samples CAB-5, XF-90, and CAU-19a, all corresponding to the interval located above the negative carbon isotope excursion. Previous work has shown that other times of global anoxia are associated with major changes in the bacterial population, and in particular the proportional contributions of cyanobacteria (e.g. Kuypers et al., 2004 -OAE2-, Xie et al., 2007 -Permian-Triassic Boundary), and future work will focus on similar changes in the Iberian region during OAE1a.

5.2.2.2. Environmental conditions. One of the main questions related to anoxic events is the geographical extent of reducing conditions in the water column. Gammacerane is present in the Puentenansa samples, and its principal source appears to be bacteriovorous ciliates, which occur at the interface between oxic and anoxic zones in stratified water columns (Sinninghé-Damsté et al., 1995; Peters et al., 2005), such that its presence is often associated with anoxia induced by water column stratification. Intriguingly, we did not detect gammacerane in the Carbonero section, even though it is characterized by the highest TOC contents, and has sedimentologic evidence of anoxia (i.e. barite concretions, Molina and Hernández-Molina, 1993; de Gea et al., 2008a).

A range of other biomarker distribution based redox proxies have been developed (e.g. Peters et al., 2005), but these are based on empirical observations of petroleum and corresponding source rocks rather than thermally immature sediments; thus, in our samples they can only be applied to the CAB and $\mathrm{PN}$ samples. The $\mathrm{Pr} / \mathrm{Ph}$ ratio has been used to infer redox conditions, but is also governed by thermal maturity, source inputs and lithology (Didyck et al., 1978; Ten Haven et al., 1987; Hughes et al., 1995). Carbonero samples have a relatively high $\mathrm{Pr} / \mathrm{Ph}$ ratio, between 2.3 and 5.5, whereas PN samples have very low values $(0.4$ and 0.5$)$, with the latter being typical for anoxic conditions $(<0.8$; Hughes et al., 1995). Other aspects of the PN biomarker profile are consistent with this, including the elevated concentrations of the $\mathrm{C}_{35}$-homohopane (Peters and Moldowan, 1991) and the high gammacerane/hopane ratios. Collectively, all of the biomarker data suggest that $\mathrm{CAB}$ samples, despite being more organic-rich, reflect more oxygenated conditions than PN samples (Fig. 12). By extension, this suggests that more reducing environments prevailed in the North Cantabrian Basin than the SIPM.

\subsection{Sedimentary model: integration of stratigraphy, geochemistry, palaeogeography and palaeoceanography}

The differences observed in the timing of deposition of the organic-rich facies between sections can be explained in relation to the different palaeogeographic settings and the palaeoceanography (Fig. 13). During Menegatti's C2 interval, the organic-rich deposition only occurs in the deep pelagic sections of the SIPM (Carbonero and La Frontera), located in fault-bounded high-subsident areas, probably with reduced water circulation, whereas in the shallow marine settings normal hemipelagic sedimentation took place (Cau) or shallow carbonate deposits (Puentenansa) were recorded (Fig. 13). This distribution could correspond to a model of deep stagnant oxygendepleted waters (i.e. Jenkyns, 1980; Pedersen and Calvert, 1990). During the $\mathrm{C} 3$ interval, an episode of environmental change affected the northern, more restricted $\mathrm{NCB}$, leading to the drowning of the Puentenansa carbonate platform and deposition of organic-rich facies (Najarro et al., 2011a), under oxygen-depleted, probably stratified, waters. Contemporaneously in the SIPM environments, a short episode of organic-rich sediment deposition took place in the shallower Cau sector, whereas in shallow carbonate platforms of the SIPM a drowning event took place (i.e. Castro et al., 2008; Castro et al., 2012). An interesting question is the temporal relationship between platform drowning and the onset of the OAE1a (i.e. Weissert et al., 1998). The data from Puentenansa indicate that the platform drowning predates the $\mathrm{C} 4$ segment, which is in agreement with previous

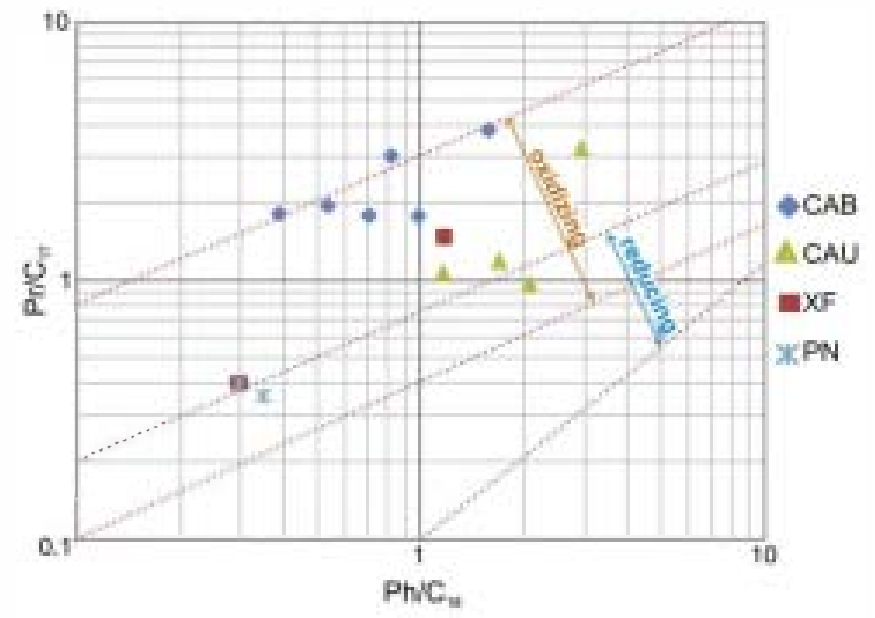

Fig. 12. $\mathrm{Pr} / \mathrm{C}_{17}$ vs. $\mathrm{Ph} / \mathrm{C}_{12}$ plot. The reference lines are from Didyck et al., 1978, but should not be interpreted against the data from less thermally mature sections (CAU and XF) as they have been empirically derived from oils and source rocks. 


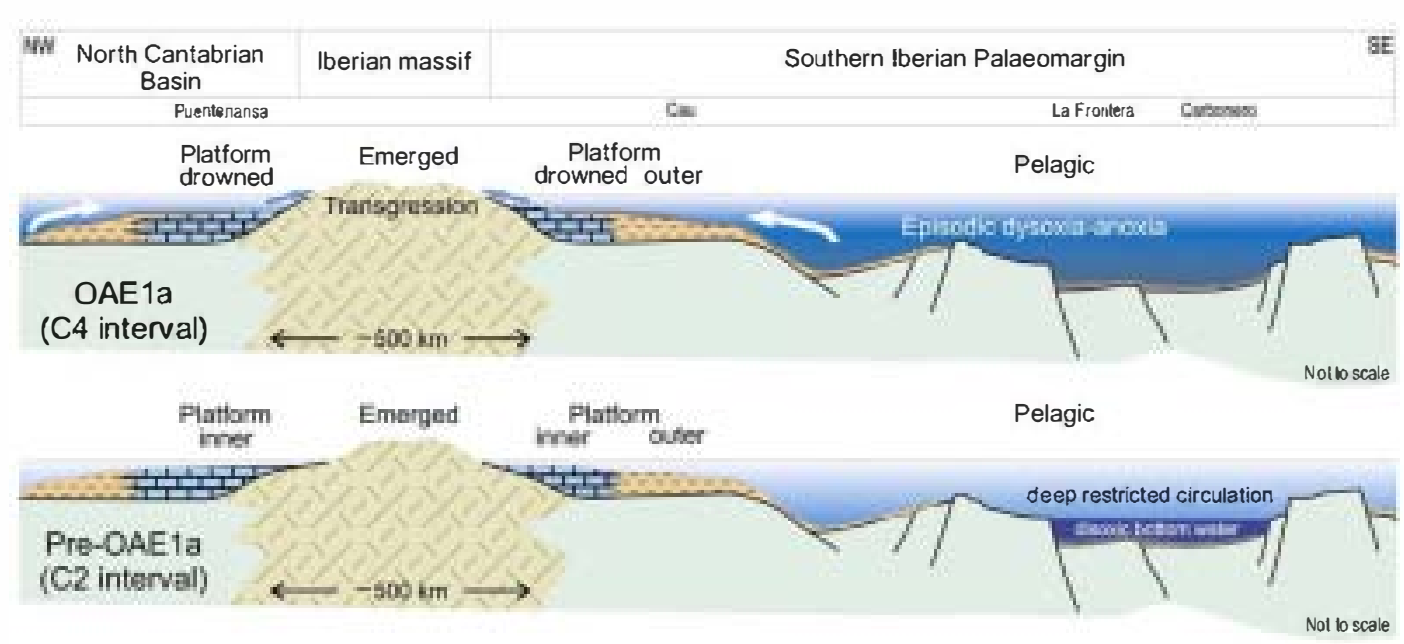

Fig. 13. Sedimentary model. See text for explanation.

studies from the Betic Cordillera (Castro et al., 2012), and also from the Subalpine Chains (Huck et al., 2011).

During the C4-C5 intervals, which corresponds to the global widespread deposition of organic matter of the OAE1a (i.e. Menegatti et al., 1998; Dumitrescu and Brassell, 2006) organic-rich sedimentation characterized all four sections. This persisted until the C8 interval, except at $\mathrm{Cau}$, where organic rich sedimentation ended during $\mathrm{C} 7$ interval. This distribution could reflect an expansion of the OMZ, reaching shallower areas on the margins, coincident with a major transgression, which could favor increased continental runoff and an increase in nutrient inputs (i.e. Burla et al., 2008; Castro et al., 2008; Blattler et al., 2011; Najarro et al., 2011a). Similar models of expansion of the OMZ have been proposed for the OAE2 (i.e. Pancost et al., 2004; Li et al., 2006).

The main factors leading to deposition of organic-rich marine sediments are anoxia and productivity (e.g. Pedersen and Calvert, 1990). Marine organic-rich sediments related to OAEs have been extensively interpreted as being deposited under anoxic or dysoxic conditions (e.g. Jenlsyns, 1980). In the Iberian sections studied here, evidence for anoxia has been found, both from sedimentology (high TOC contents, barite concretions, laminations, lack of bioturbation, planktonic associations...), and biomarkers (presence of gammacerane, distribution of homohopanes, $\mathrm{Pr} / \mathrm{Ph}$ ratios, isoprenoids/n-alkane ratios). However, the signature for anoxia is neither unambiguous nor widespread. Differences among sections are interesting: Carbonero section shows a stronger sedimentologic signal of anoxia (i.e. highest TOC contents), whereas the biomarker proxies of these conditions are weak. Although deeper studies are needed about redox proxies for the Carbonero section, a high productivity environment should be also considered; this is consistent with the presence of $\mathrm{Ba}$, which has been proposed as a powerful proxy for productivity in marine environments (Paytan and Griffith, 2007), although more detailed investigation on this element are necessary to avoid misinterpretations. The other SIPM sections (La Frontera and Cau) show both sedimentary and biomarker evidence of anoxia, as stated before. On the other hand, the NCB section (Puentenansa) shows stronger biomarker evidence for anoxia (presence of gammacerane, homohopane distributions, $\mathrm{Pr} / \mathrm{Ph}$ ratios), which can be related to the palaeogeographic setting in the Bay of Biscay, probably with a more restricted communication of the waters to the open ocean.

Finally, although the sections studied represent different sedimentary environments (platform and pelagic), there are no systematic biomarker differences related to this, for example, there is no evidence for greater terrigenous $\mathrm{OM}$ inputs to the platform settings.
Instead, the main differences in biomarker distributions are associated with thermal maturity and vertical variability.

\section{Conclusions}

Four sections recording the Early Aptian OAE1a in Spain have been characterized by biostratigraphy, C-isotope stratigraphy, elemental geochemis y, biomarker distribution, and sedimentology; the sections represent different palaeogeographic (North Cantabrian Basin and Southern Iberian Palaeomargin) and geotectonic settings (pelagic and shallow marine). The $\mathrm{C}$-isotope curves allowed the recognition of the eight segments proposed by Menegatti et al. (1998) and subsequently identified in sections from around the world, and the integration of biostratigraphic and C-s ratigraphic data was used to develop an integrated stratigraphic framework, allowing correlation of the Iberian OAE1a. Biomarker distributions revealed significant variations in thermal maturity, which was very low in the Cau and La Frontera sections, moderate in the Puentenansa samples, but relatively high for the Carbonero section, which is within the oil window. The strong lateral variations in maturity over short distances were interpreted as probably due to volcanic activity or burial history. Overall, all of the OM present in the studied samples is interpreted to derive from significant terrestrial inputs as well as marine and bacterial sources, and dinosterane was particularly abundant in several samples. Environmental proxies indicatives of anoxia-dysoxia occur in all the sections, but evidence for strong and persistent water column anoxia is equivocal. Crucially, however, the correlation of the sections reveals that deposition of organic-rich facies started earlier in pelagic setings and later in the platform settings, which can be related to an expansion of the oxygen minimum zone from deep marine waters to shallower marine environments during the development of the OAE1a.

\section{Acknowledgments}

We would like to specially thank Prof. Pedro A. Ruiz-Ortiz for his support and encouragement with this research. This work is a contribution of the research projects UJA-07-16-41 (University of Jaen), CGL2011-24546 and CGL2009-10329 (Spanish Ministry of Science and Technology), IEG617028019 (Instituto de Estudios Giennenses) and RNM-200 (Junta de Andalucia). Authors wish to thank Marina Sánchez Royo for her help in the laboratory work. We thank Adrian Immenhauser, Finn Surlyk and an anonymous reviewer for their helpful comments and critical reviews. 


\section{References}

Aguado, R., Castro, J.M., Company, M., de Gea, G.A., 1999. Aptian bioevents-an inte grated biostratigraphic analysis of the Almadich Formation, Inner Prebetic Domain, SE Spain. Cretaceous Research 20, 663-683.

Aguado, R., Company, M., O'Dogherty, L., Sandoval, J., Tavera, J.M., 1992a. Biostrati graphic analysis of the pelagic Barremian/Aptian in the Betic Cordillera (Southern Spain). Prelimiary data. Cretaceous Research 13, 445-452.

Aguado, R., Molina, J.M., O'Dogherty, L., 1992b. Bioestratigrafía y litoestratigrafia de la Formación Carbonero (Barremiense-Albiense?) en la transición Subbético Externo-Subbético Medio (Sur de Jaén). Cuadernos de Geologia Iberica 17, 325-344

Aguado, R., O'Dogherty, L., Sandoval, J., 2008. Fertility changes in surface waters during the Aalenian (mid Jurassic) of the Western Tethys as revealed by calcareous nannofossils and carbon-cycle perturbations. Marine Micropaleontology 68 268-285.

Ando, A, Kakegawa, T., Takashima, R., Saito, T., 2002. New perspective on Aptian carbon isotope stratigraphy: data from $8^{13} \mathrm{C}$ records of terrestrial organic matter. Geology $30,227-230$.

Arthur, M.A.,Jenkyns, H.C., Brumsack, H., Schlanger, S.O., 1990. Stratigraphy, geochem istry, and paleoceanography of organic carbon-rich Cretaceous sequences. In: Ginsburg, R.N., Beaudoin, B. (Eds.), Cretaceous Resources, Events and Rhythms NATO AS1 Series C, 304. Kluwer Academic, Dordrecht, pp. 75-119.

Azéma, J., Foucault, A, Fourcade, E., García Hernández, M., González Donoso, J.M. Linares, A, Linares, D., López Garrido, A.C, Rivas, P., Vera, J.A., 1979. Ias microf acies del Jurásico y Cretácico de las Zonas Externas de las Cordilleras Béticas. Universidad de Granada (83 pp.).

Beerling, D.J., Royer, D.L., 2002. Fossil plants as indicators of the Phanerozoic global carbon cycle. Annual Review of Earth and Planetary Sciences 30, 527-556.

Blattler, C.L., Jenkyns, H.C., Reynard, L.M., Henderson, G., 2011. Significant increases in global weathering during Oceanic Anoxic Events $1 \mathrm{a}$ and 2 indicated by calcium isotopes. Earth and Planetary Science Letters 309, 77-88.

Bourbonniere, R.A., Meyers, P.A., 1996. Sedimentary geolipid records of historical changes in the watersheds and productivities of Iakes Ontario and Erie. Limmology and Oceanography $41,352-359$

Bover-Arnal, T., 2010. The Aptian evolution of the Galve sub-basin (Maestrat Basin; E Iberia). Ph.D. Thesis. Universität Bayreuth, $209 \mathrm{pp}$.

Bown, P., 2005. Selective calcareous nannoplankton survivorship at the Cretaceous Tertiary boundary. Geology 33, 653-656.

Bown, P.R., Young, J.R., 1998. Techniques. In: Bown, P.R. (Ed.), Calcareous Nannofossil Biostratigraphy. Chapman \& Hall, Iondon, pp. 16-28.

Bralower, T.J., Arthur, M.A., Lecke, R.M., Sliter, W.V., Allard, D.J., Schlanger, S.O., 1994 Timing and paleoceanography of oceanic dysoxia/anoxia in the Iate Barremian to Early Aptian (Early Cretaceous). Palaios 9, 335-369.

Bralower, T.J., CoBabe, E., Clement, B., Sliter, W.V., Osburn, C.L., Longoria, J., 1999. The record of global change in Mid-Cretaceous (Barremian-Albian) sections from the Sierra Madre, northeastern Mexico. Journal of Foraminiferal Research 29, 418-437.

Bréheret, J.G., Brumsack, H.J., 2000. Barite concretions as evidence of pauses in sedimentation in the Marnes Bleues Formation of the Vocontian Basin (SE France) Sedimentary Geology 130, 205-228.

Burla, S., Heimhofer, U., Hochuli, P.A., Weissert, H., Skelton, P., 2008. Changes in sedimentary patterns of coastal and deep-sea successions from the North Atlantic (Portugal) linked to Early Cretaceous environmental change. Palaeogeography Palaeoclimatology, Palaeoecology 257, 38-57.

Busson, G., Noël, D., 1991. Les nannoconidés, indicateurs environmentaux des océans et mers épicontinentales duJurassique terminal et du Crétacé inférieur. Oceanologica Acta 14, 333-356.

Castro, J.M. 1998. Ias plataformas del Valanginiense superior-Albiense superior en el Prebético de Alicante. Ph.D. Thesis. University of Granada, 464 pp.

Castro, J.M., de Gea, G.A., Ruiz-Ortiz, P.A., Nieto, L.M., 2008. Development of carbonate platforms on an extensional (rifted) margin. The Valanginian-Albian record of the Prebetic of Alicante (SE Spain). Cretaceous Research 29, 848-860.

Castro, J.M., de Gea, G.A., Ruiz-Ortiz, P.A., Quijano, M.L., Pancost, R.D., Jimenez de Cisneros, C., Caballero, E., 2012. Stratigraphy and geochemistry of an early Aptian carbonate platform: interactions between relative sea level and environmental changes (Prebetic Zone, Spain). Geophysical Research Abstracts 14 (EGU2012-6217-1).

Caus, E., Bernaus, J.M., Calonge, E., Martín-Chivelet, J., 2009. Mid-Cenomanian separation of Atlantic and Tethyan domains in Iberia by a land-bridge: the origin of larger foraminifera provinces? Palaeogeography, Palaeoclimatology, Palaeoecology 283, 172-181.

Caus, E., Hottinger, L., 1986. Particularidades de la fauna (foraminíferos) del Cretácico superior pirenaico. Paleontologia i Evolució 20,115-123.

Didyck, B.M., Simoneit, B.R.T., Brassel, S.C., Eglinton, G., 1978. Organic geochemical in dicators of palaeoenvironmental conditions of sedimentation. Nature 272 216-222.

Dumitrescu, M., Brassell, S.C., 2005. Biogeochemical assessment of sources of organic matter and paleoproductivity during the Early Aptian Oceanic Anoxic Event at Shatsky Rise, ODP Leg 198. Organic Geochemistry 36, 1002-1022.

Dumitrescu, M., Brassell, S.C., 2006. Compositional and isotopic characteristics of or ganic matter for the Early Aptian Oceanic Anoxic Event at Shatsky Rise, ODP Leg 198. Palaeogeography, Palaeoclimatology, Palaeoecology 235, 168-191.

Dumitrescu, M., Brassell, S.C., Schouten, S., Hopmans, E.C., Sinninghe-Damste, J.S., 2006 Instability in tropical Pacific sea-surface temperatures during the early Aptian. Geology $34(10), 833-836$

Eglinton, G., Hamilton, R.J., 1967. Leaf epicuticular waxes. Science 156, 1322-1335.

Erba, E., 1994. Nannofossils and superplumes: the early Aptian "nannoconid crisis". Paleoceanography $9,483-501$. phytoplankton response to nutrification episodes, atmospheric $\mathrm{CO} 2$, and anoxia Paleoceanography $19 \mathrm{http}: / / \mathrm{dx}$.doi.org/10.1029/2003PA00084.

Erba, E., Bottini, C., Weissert, H., Keller, C.E., 2010. Calcareous nannoplankton response to surface-water acidification around Oceanic Anoxic Event 1a. Science 329, 428 http://dx.doi.org/10.1126/science. 1188886.

Erbacher, J., Huber, B.T., Norris, R.D., Markey, M., 2001. Increased thermohaline stratification as a possible cause for an ocean anoxic event in the cretaceous period. Na ture 409, 325-327.

Feuillée, P., Rat, P., 1971. Structures et paléogéographies Pyrénéo-Cantabriques Histoire Structurale du Golfe de Gascogne. Publication de l'Institute Français du Pétrole: Collection Colloque et Séminaires, Technip, Paris, 22, pp. 1-48.

Föllmi, K.B., Godet, A, Bodin, S., Linder, P., 2006. Interactions between environmental change and shallow water carbonate buildup along the northern Tethyan margin and their impact on the Early Cretaceous carbon isotope record. Paleoceanography 21, PA4211 http://dx.doi.org/10.1029/2006PA001313.

García Hernández, M., López Garrido, AC., Sanz de Galdeano, C., Vera, J.A., Rivas, P., 1980. Mesozoic paleogeographic evolution in the External Zones of the Betic Cordillera (Spain). Geologie en Mijnbouw 59, 155-168.

García-Senz,J., Robador, A, 2009. Variation in structural style at a lateral termination of a basement-involved wedge: the margin of the West Cantabrian basin. 6th Symposium on the Atlantic Iberian Margin, Oviedo, Spain, pp. 61-64

de Gea, G.A., Aguado, R., Castro, J.M., Molina,J.M., Ruiz Ortiz, P.A., 2005. Subbetic anoxic Lower Aptian facies (Carbonero Fm., External Zones of the Betic Cordillera, S Jaén, Spain) and the OAEla. 7th International Symposium on the Cretaceous, Scientific Program and Abstracts, pp. 65-66 (Neuchâtel).

de Gea, G.A., Aguado, R., Castro, J.M., Molina, J.M., Ruiz Ortiz, P.A., 2008a. Registro del evento anóxico del Aptiense inferior en la cuenca subbética (Sur de Jaén): La Formación Carbonero. VII Congreso Geológico de España. Las Palmas de Gran Canaria, 14-18 Julio.

de Gea, G.A. 2004. Binestratigrafía y eventos del Cretácico Inferior en las Zonas Externas de la Cordillera Bética. Servicio de Publicaciones de la Universidad de Jaén, Jaén . (658 pp.)

de Gea, G. A. A guado, R., Castro, J.M., 2008b. Variaciones en el registro isotópico del carbono en dos secciones de edad Aptiense inferior en la zona de transición entre el Subbético Externo y el Subbético Medio (Cordilleras Béticas, Provincia de Jaén). Geogaceta 44, 191-194.

de Gea, G.A., Aguado, R., Castro,J.M., Molina,J.M., O'Dogherty, L., Ruiz-Ortiz, P.A., 2008c Early Aptian Subbetic organic-rich facies, radiolarites and associated deposits. The local expression of the Oceanic Anoxic Event 1a (Carbonero Formation, Southern Spain). Cretaceous Research 29, 861-870.

de Gea, G.A., Castro, J.M., Aguado, R., Company, M., Ruiz-Ortiz, P.A., 2003. Lower Aptian carbon-isotope stratigraphy from a distal carbonate shelf setting. The Cau section Prebetic Zone, SE of Spain. Palaeogeography, Palaeoclimatology, Palaeoecology 200, 207-219.

Gran, H.H., Braarud, T., 1935. A quantitative study of the phytoplankton in the Bay of Fundy and the Gulf of Maine (including observations of the hydrogeology, chemistry and turbidity). Journal of the Biological Board of Canada 1, 279-467.

Gröcke, D.R., Hesselbo, S.P., Jenkyns, H.C., 1999. Carbon-isotope composition of Lower Cretaceous fossil wood: ocean-atmosphere chemistry and relation to sea-level change. Geology 27, 155-158.

Hallam, A, 1985. A review of Mesozoic climate. Journal of the Geological Society of London 142, 433-445.

Hay, W.W., 2008. Evolving ideas about the Cretaceous climate and ocean circulation. Cretaceous Research 29, 725-753.

Heimhofer, U., Hochuli, P.A., Herrle, J.O., Andersen, N., Weissert, H., 2004. Absence of major vegetation and palaeoatmospheric $\mathrm{pCO} 2$ changes associated with oceanic anoxic event 1a (Early Aptian, SE France). Earth and Planetary Science Letters 223, 303-318.

Hermoso, M., Le Callonnec, L., Minoletti, F., Renard, M., Hesselbo, S.P., 2009. Expression of the Early Toarcian negative carbon-isotope excursion in separated carbonate microfractions (Jurassic, Paris Basin). Earth and Planetary Science Letters 277, 194-203.

Herrle, J.O., Kößler, P., Friedrich, O., Erlenkeuser, H., Hemleben, C., 2004. High-resolution carbon isotope records of the Aptian to Iower Albian from SE France and the Mazgan Plateau (DSDP Site 545): a stratigraphic tool for paleoceanographic and paleobiologic reconstruction. Earth and Planetary Science Ietters 218, 149-161.

Hochuli, P.A., Menegatti, A.P., Weissert, H., Riva, A, Erba, E., Premoli Silva, I., 1999 Episodes of high productivity and cooling in the early Aptian Alpine Tethys. Geology $27,657-660$

Huang, W.Y., Meinschein, W.G., 1979. Sterols as ecological indicators. Geochimica et Cosmochimica Acta 43, 739-745.

Huber, B.T., Hodell, D.A., Hamilton, C.P., 1995. Middle-Iate Cretaceous climate of the southern high latitudes: stable isotopic evidence for minimal equator-to-pole thermal gradients. Geological Society of America Bulletin 107, 1164-1191.

Huck, S., Heimhofer, U., Rameil, N., Bodin, S., Immenhauser, A, 2011. Strontium and carbon-isotope chronostratigraphy of Barremian-Aptian shoal-water carbonates: Northern Tethyan platform drowning predates OAE 1a. Earth and Planetary Science Ietters $304,547-558$

Huck, S., Rameil, N., Korbar, T., Heimhofer, U., Wieczorek, T.D., Immenhauser, A, 2012. Latitudinally different responses of Tethyan shoal-water carbonate systems to the Early Aptian oceanic anoxic event (OAE 1a). Sedimentology 57, 1585-1614

Hughes, W.B., Albert, T., Holba, G., Dzou, L., 1995. The ratios of dibenzothiophene to phenanthrene and pristane to phytane as indicators of depositional environment and lithology of petroleum source rocks. Geochimica et Cosmochimica Acta 59 3581-3598. 
Immenhauser, A., Hillgärtner, H., van Bentum, E., 2005. Microbial-foraminiferal episodes in the Early Aptian of the southern Tethyan margin: ecological significance and possible relation to Oceanic Anoxic Event 1a. Sedimentology 52, 77-99.

Immenhauser, A., Schlager, W., Burns, S.J., Scott, R.W., Geel, T., Lehmann, J., et aI., 1999. Late Aptian to Late Albian sea-level fluctuations constrained by geochemical and biological evidence (Nahr Umr Fm Oman). Journal of Sedimentary Research 69 , 434-446.

Immenhauser, A., 2005. High-rate sea-level change during the Mesozoic: new approaches to an old problem. Sedimentary Geology 175, 277-296.

Jahren, A.H., Conrad, C.P., Crystal Arens, N., Mora, G., Lithgow-Bertelloni, C., 2005. A plate tectonic mechanism for methane hydrate release along subduction zones. Earth and Planetary Science Ietters 236, 691-704.

Jenkyns, H.C., 1980. Cretaceous anoxic events: from continents to oceans. Journal of the Geological Society of Iondon 137, 171-188.

Jenkyns, H.C., 1995. Carbon isotope stratigraphy and paleoceanographic significance of the Iower Cretaceous shallow water carbonates of Resolution Guyot, mid-Pacific Mountains. In: Winterer, E.L., Sager, W.W., Firth, V.J., Sinton, M. (Eds.), Proceedings of the Ocean Drilling Program, Scientific Results, 143. College Station, Texas, pp. 89-97.

Jenkyns, H.C., 2010. Geochemistry of oceanic anoxic events. Geochemistry Geophysics Geosystem 11, Q03004 http://dx.doi.org/10.1029/2009GC002788.

Jenkyns, H.C., 2003. Evidence for rapid climate change in the Mesozoic-Palaeogene greenhouse world. Philosophical Transactions of the Royal Society of Iondon. Series A 361, 1885-1916.

Jenkyns, H.C., Schouten-Huibers, L., Schouten, S., Sinninghe-Damsté, J.S., 2012. Warm Middle Jurassic-Early Cretaceous high-latitude sea-surface temperatures from the Southern Ocean. Climate of the Past 8, 215-226.

Kuypers, M.M.M., Iourens, L., Rijpstra, W.LC, Pancost, R.D., Nijenhuis, LA, Sinninghe Damsté, J.S., 2004. Orbital forcing of organic carbon burial in the proto-North Atlantic during Oceanic Anoxic Event 2. Earth and Planetary Science Ietters 228, 465-482.

Iarson, R.L., 1991. Iatest pulse of the Earth: evidence for a mid-Cretaceous super plume. Geology 19, 547-550.

Iarson, R.L., Erba, E., 1999. Onset of the mid-Cretaceous greenhouse in the BarremianAptian: igneous events and the biological, sedimentary and geochemical responses. Paleoceanography $14,663-678$.

Leckie, R.M., Bralower, T.J., Cashman, R., 2002. Oceanic anoxic events and plankton evolution: biotic response to tectonic forcing during the mid-Cretaceous. Paleoceanography 17 http://dx.doi.org/10.1029/2001PA000623.

Iees, J.A., Bown, P.R., Mattioli, E., 2005. Problemswithproxies? Cautionarytales of calcareous nannofossil paleoenvironmental indicators. Micropaleontology 51, 333-343.

Mutterlose, J., 1992. Biostratigraphy and palaeobiogeography of Early Cretaceous calcareous nannof ossils. Cretaceous Research 13, 167-189.

Li, Y.-X., Bralower, T.J., Montañez, LP., Osleger, D.A., Arthur, M.A., Bice, D.M., Herbert, T.D., Erba, E., Premoli Silva, I., 2008. Toward an orbital chronology for the early Aptian Oceanic Anoxic Event (OAE1a, $120 \mathrm{Ma}$ ). Earth and Planetary Science Letters $271,88-100$.

Li, X., Jenkyns, H.C., Wang, C., Hu, X., Chen, X., Wei, Y., Huang, Y., Cui, J., 2006. Upper Cretaceous carbon- and oxygen-isotope stratigraphy of hemipelagic carbonate facies from southern Tibet, China. Journal of the Geological Society of London 163, 375-382.

Luciani, V., Cobianchi, M., Jenkyns, H.C., 2001. Biotic and geochemical response to anoxic events: the Aptian pelagic succession of the Gargano Promontory (southern Italy). Geological Magazine 138, 277-298.

Mackenzie, A., Patience, R.L., Maxwell,J.R., Vandenbroucke, M., Durand, B., 1980. Molecular parameters of maturation in the Toarcian shales, Paris Basin, France-I. Changes in the configurations of acyclic isoprenoid alkanes, steranes and triterpanes. Geochimica et Cosmochimica Acta 44, 1709-1721.

Martín-Chivelet, J., Berasategui, X., Rosales, I., Vilas, L., Vera, J.A., Caus, E., Gráfe, K.U., Mas, R., Puig, C., Segura, M., Robles, S., Floquet, M., Quesada, S., Ruiz-Ortiz, P.A. Frenegal-Martínez, M.A., Salas, R., García, A., Martín-Algarra, A., Arias, C. Meléndez, M., Chacón, B., Molina, J.M., Sanz, J.L., Castro, J.M., García-Hernández, M., Carenas, B., García-Hidalgo, J., Gil, J., Ortega, F., 2002. Cretaceous. In: Gibbons, W. Moreno, T. (Eds.), The Geology of Spain. The Geological Society, London, pp. $255-292$

Masse, J.P., Bowaziz, S., Amon, E.O., et aI., 2000. Early Aptian. (94.7-93.5 Ma). In: Dercourt, J., Gaetani, M., Vrielynck, B., Barrier, E., Biju-Duval, B., Brunet, M.F., Cadet, J.P., Crasquin, S., Sandulescu, M. (Eds.), Peri-Tethys Palaeogeographical Atlas. CCGM/CGMW, Paris (Map 13).

Mehay, S., Keller, C.E., Bernasconi, S., Weissert, H., Erba, E., Bottini, C., Hochuli, P.A 2009. A volcanic $\mathrm{CO}_{2}$ pulse triggered the Cretaceous Oceanic Anoxic Event $1 \mathrm{a}$ and a biocalcification crisis. Geology 37, 819-822 http://dx.doi.org/10.1130/G30100A.

Menegatti, A.P., Weissert, H., Brown, R.S., Tyson, R.V., Farrimond, P. Strasser, A Caron, M., 1998. High-resolution $8^{13} \mathrm{C}$ stratigraphy through the early Aptian "Livello Selli" of the Alpine Tethys. Paleoceanography $13,530-545$.

Meyers, P.A., 1997. Organic geochemical proxies of paleoceanographic, paleolimnologic and paleoclimatic processes. Organic Geochemistry 27, 213-250.

Millán, M.L, Weissert, H.J., Fernández-Mendiola, P.A., García-Mondéjar, J., 2009. Impact of Early Aptian carbon cycle perturbations on evolution of a marine shelf system in the Basque-Cantabrian Basin (Aralar, N Spain). Earth and Planetary Sciences letters $287,392-401$

Moldovan, J.M., Seifert, W.K., Gallegos, E.J., 1985. Relationship between petroleum composition and depositional environment of petroleum source rocks. American Association of Petroleum Geologists Bulletin 69, 1255-1268.

Molina, J.M, de Gea, G.A., Aguado, R., 2001. Facies anóxicas, radiolaríticas y turbidíticas en el Cretácico de la Zona Subbética: la Formación Carbonero. In: Ruiz-Ortiz PA Molina, J.M., Nieto, L.M., Castro, J.M., Gea, G.A. (Eds.), Itinerarios geológicos por el
Mesozoico de la provincia de Jaén. Departamento de Geología. Universidad de Jaén, pp. 41-60

Molina, J.M., Hernández-Molina, F.J., 1993. Concreciones de barita en el Cretácico (Aptiense-Albiense) del Subbético (Cordilleras Béticas). Boletín Geológico y Minero $104,548-573$.

Molina, J.M., Vera, J.A., de Gea, G.A., 1998. Vulcanismo submarino del Santoniense en el Subbético: Datación con nannofósiles e Interpretación (Formación Capas Rojas, Alamedilla, Provincia de Granada). Estudios Geológicos 54, 191-197.

Najarro, M., Rosales, I., 2008a. Disoluciones e incrustaciones ferruginosas asociadas al OAE 1a en la plataforma carbonatada de La Florida (NO de Cantabria). Geogaceta 44, 199-202.

Na jarro, M., Rosales, I., 2008b. Evidencias sedimentológica, diagenética y quimioestratigráfica del Evento Anóxioo Oceánió del Aptiense Inferior (OAE 1a) en la plataforma carbonatada de Ia Florida (NO de Cantabria). Geo-Temas 10, 163-166.

Na jarro, M., Peñalver, E., Rosales, I., Pérez-de la Fuente, R., Daviero-Gomez, V., Gomez, B., Delclòs, X., 2009. Unusual concentration of Early Albian arthropod-bearing amber in the Basque-Cantabrian Basin (El Soplao, Cantabria, Northern Spain): palaeoenvironmental and palaeobiological implications. Geologica Acta 7, 363-387.

Na jarro, M., Rosales, I., Martín-Chivelet, J., 2011a. Major palaeoenvironmental perturbation in an Early Aptian carbonate platform: prelude of the Oceanic Anoxic Event 1a? Sedimentary Geology 235, 50-71.

Najarro, M., Rosales, I., Martín-Chivelet, J., 2007. Evolución de la plataforma carbonatada de la Florida durante el rifting del Cretácico Inferior (Aptiense, NO de Cantabria). In: Bermúdez, D.D, Najarro, M. Quesada, C (Eds.) Volumen Monográfico de la II Semana de Jóvenes Investigadores del IGME. Publicaciones del IGME, pp. 123-128.

Najarro, M., Rosales, L, Moreno-Bedmar, J.A., de Gea, G., Barrón, E., Company, M., Delanoy, G., 2011b. High-resolution chemo- and biostratigraphic records of the Early Aptian oceanic anoxic event in Cantabria (N Spain): palaeoceanographic and palaeoclimatic implications. Palaeogeography, Palaeoclimatology, Palaeoecology 299, 137-158 http://dx.doi.org/10.1016/j.palaeo.2010.10.042.

Olivet, J.M., 1996. Ia cinématique de la plaque ibérique. Bulletin des Centres de Recherches Exploration-Production Elf-Aquitaine 20, 131-195.

Ourisson, G., Albrecht, P., Rohmer, M., 1982. Predictive microbial biochemistry from molecular fossils to prokaryotic membranes. Trends in Biochemical Sciences 7, 236-239.

Pancost, R.D., Crawford, N., Magness, S., Turner, A., Jenkyns, H.C., Maxwell, J.R., 2004 Further evidence for the development of photic-zone euxinic conditions during Mesozoic oceanic anoxic events. Journal of the Geological Society of London 161, 353-364

Parker, M.E., Clark, M., Wise, S.W., 1985. Calcareous nannofossils of Deep Sea Drilling Project Sites 558 and 563, North Atlantic Ocean: biostratigraphy and the distribution of Oligocene braarudosphaerids. Initial Reports of the Deep Sea Drilling Project 82, 559-589.

Paytan, A., Griffith, E.M., 2007. Marine barite: recorder of variations in ocean export productivity. Deep-Sea Research II 54, 687-705.

Pedersen, T.F., Calvert, S.E., 1990. Anoxia vs. productivity: what controls the formation of organic-carbon-rich sediments and sedimentary rocks. American Association of Petroleum Geologists Bulletin 74, 454-466

Peters, K.E., Moldowan,J.M., 1991. Effects of source, thermal maturity, and biodegradation on the distribution and isomerization of homohopanes in petroleum. Organic Geochemistry $17,47-51$.

Peters, K.E., Walters, C.C., Moldowan, J.M., 2005. 2nd ed. The Biomarker Guide, voL 2. Cambridge University Press (1155pp.)

Powell, T.G., McKirdy, D.M., 1973. Relationship between ratio of pristane to phytane, crude oil composition and geological environment in Australia. Nature 243, 37-39.

Price, G.D., 2003. New constraints upon isotope variation during the early Cretaceous (Barremian-Cenomanian) from the Pacific Ocean. Geological Magazine 140 $513-522$

Rameil, N., Immenhauser, A., Warrlich, G., Hillgärtner, H., Droste, H.J., 2010. Morphological patterns of Aptian Lithocodium-Bacinella geobodies: relation to environment and scale. Sedimentology 57, 883-911.

Rosales, I., Na jarro, M., Moreno-Bedmar, J.A., de Gea, G.A., Company, M., 2009. High resolution chemo- and biostratigraphic records of the Early Aptian Oceanic Anoxic Even in Cantabria (northern Spain). Geochimica et Cosmochimica Acta 73 (13S), A1118.

Roth, P.H., Bowdler, J.L., 1981. Middle Cretaceous nannoplankton biogeography of the Atlantic Ocean. The Society of Economic Paleontologists and Mineralogists Special Publication 32, 517-546.

Roth, P.H., Krumbach, K.R., 1986. Middle Cretaceous calcareous nannofossil biogeography and presevation in the Atlantic and Indian oceans: implications for paleoceanography. Marine Micropaleontology 10, 235-266.

Ruiz-Ortiz, P.A., 1980. Análisis de facies del Mesozoico de las Unidades Intermedias (entre Castril-provincia de Granada-y Jaén). Ph.D. Thesis. University of Granada, 372 pp.

Ruiz-Ortiz, P.A. Molina, J.M., Nieto, L.M., Castro, J.M., de Gea, G., 2001. Itinerarios geológicos por el Mesozoico de la provincia de Jaén. 1. Introducción al Mesozoico de la parte externa del paleomargen sudibérico. Cordillera Bética: IV Coloquio del Cretácico de España, University of Jaén, pp. 11-24.

Scalan, R.S., Smith, J.E., 1970. An improved measure of the odd-even predominance in the normal alkanes of sediment extracts and petroleum. Geochimica et Cosmochimica Acta 34, 611-620.

Scarparo-Cunha, A.A., Shimabukuro, S., 1997. Braarudosphaera blooms and anomalous enrichments of Nannoconus: evidence from the Turonian South Atlantic, Santos Basin, Brazil. Journal of Nannoplankton Research 19, 51-55.

Schlanger, S.O., Jenkyns, H.C., 1976. Cretaceous oceanic anoxic events: causes and consequences. Geologie en Mijnbouw 55, 179-184

Seifert, W.K., Moldowan, J.M., 1980. The effect of thermal stress on source-rock quality as measured by hopane stereochemistry. Physics and Chemistry of the Earth 12, 229-237. 
Siesser, W.G., Bralower, T.J., De Carlo, E.H., 1992. Mid-Tertiary Braarudosphaera-rich sediments on the Exmouth Plateau. Proceedings of the Ocean Drilling Program, Scientific Results 122, 653-663.

Sinninghé-Damsté, J.P., Kenig, F., Koopmans, M.P., Koster, J.G., Schouten, S., Hayes, J.M. De Leeljw, J.W., 1995. Evidence for gammacerane as an indicator of water column stratification. Geochimica et Cosmochimica Acta 59, 1895-1900.

Skelton, P.W. (Ed.), 2003. The Cretaceous World. The Open University, Milton Keynes, and Cambridge University Press, Cambridge (360pp.)

Stein, M., Föllmi, K.B., Westermann, S., Godet, S., Adatte, T., Matera, V, Fleitmann, D., Berner, 2., 2011. Progressive palaeoenvironmental change during the Late Barremian-Early Aptian as prelude to Oceanic Anoxic Event 1a: evidence from the Gorgo a Cerbara section (Umbria-Marche basin, central Italy). Palaeogeography, Palaeoclimatology, Palaeoeoology http://dx.doi.org/10.1016/j.palaeo.2011.01.025.

Street, C., Bown, P.R., 2000. Palaeobiogeography of Early Cretaceous (BerriasianBarremian) calcareous nannoplankton. Marine Micropaleontology 39, 265-291.

Summons, R.E., Volkman, J.K., Boreham, C.J., 1987. Dinosterane and other steroidal hydrocarbons of dinollagellate origin in sediments and petroleum. Geochimica et Cosmochimica Acta 51, 3075-3082.

Tejada, M.L., Suzuki, K., Kuroda, J., Coccioni, R., Mahoney, J.J., Ohkouchi, N., Sakamoto, N., Tatsumi, Y., 2009. OntongJava Plateau eruption as a trigger for the early Aptian oceanic anoxic event. Geology 37, 855-858 http://dx.doi.org/10.1130/G25763A.

Ten Haven, H.L., de Leeuw, J.W., Rullköter, J., Sinninghe Damsté, J.S., 1987. Restricted utility of the pristane/phytane ratio as a palaeoenvironmental indicator. Nature $330,641-643$.

Thierstein, H.R., 1976. Mesozoic calcareous nannoplankton biostratigraphy of marine sediments. Marine Micropaleontology 1, 325-362.

Tremolada, F., Erba, E., 2002. Morphometric analyses of Aptian Assipetra infracretacea and Rucinolithus terebrodentarius nannoliths: implications for taxonomy, biostratigraphy and palaeoceanography. Marine Micropaleontology 44, 77-92.
Vera, J.A., (Coord.), 2004. Cordillera Bética y Baleares. In: Vera, J.A. (Ed.), Geología de España SGE-IGME, Madrid, 347-464.

Vera, J.A., 1988. Evolución de los sistemas de depósito en el margen ibérico de la Cordillera Bética. Revista Sociedad Geológica España 1, 373-391.

Vergès, J., García-Senz, J., 2001. Mesozoic evolution and Cainozoic inversion of the Pyrenean Rift. In: Ziegler, P.A., Cavazza, W., Robertson, A.H.F., Crasquin-Soleau, J. (Eds.), Peri-Tethys Memoir 6: Peri-Tethyan Rift/Wrench Basins and Passive Margins: Mémoires du Muséum National d'Historie Naturelle, Paris, 186, pp. 187-212.

Waples, D.W., Machihara, T., 1991. Biomarkers for geologists. American Association of Petroleum Geologists-Methods in Exploration Series, 9 (91pp.).

Weissert, H., Erba, E., 2004. Volcanism, $\mathrm{CO} 2$ and palaeoclimate: a Late Jurassic-Early Cretaceous carbon and oxygen isotope record. Journal of the Geological Society of London 161, 695-702.

Weissert, H., Lini, A, Föllmi, K.B., Kuhn, O., 1998. Correlation of Early Cretaceous carbon isotope stratigraphy and platform drowning events: a possible link? Palaeogeography, Palaeoclimatology, Palaeoecology 137, 189-203.

Wilson, P.A., Norris, R.D., 2001. Warm tropical ocean surface and global anoxia during the mid-Cretaceous period. Nature 412, 425-428.

Wissler, L., Funk, H.P., Weissert, H., 2003. Response of Early Cretaceous carbonate platforms to changes in atmospheric carbon dioxide levels. Palaeogeography, Palaeoclimatology, Palaeoecology 200, 187-205.

Withers, N., 1983. Dinoflagellatesterols. In: Scheuer, P.J. (Ed.), Marine Natural Products, 5. Academic Press, New York, pp. 87-130.

Xie, S., Pancost, R.D., Huang, X., Jiao, D., Lu, L., Huang, J., Yang, F., Evershed, R.P., 2007. Molecular and isotopic evidence for episodic environmental change across the Permo//riassic boundary at Meishan in South China. Global and Planetary Change 55, 56-65.

Ziegler, P.A., 1988. Evolution of the Artic-North Atlantic and the Western Tethys, publ. Int. lithos. Program, 0144. AAPG Memoir 43 (193pp.). 